\title{
Introduction: Provincialising the Rise of the British Novel in the Transatlantic Public Sphere
}

When I began working on this book in 2011, the 2007 bicentennial of the abolition of the slave trade still felt recent. ${ }^{1}$ There were new films, exhibitions, and a plethora of events commemorating and reflecting Britain's involvement in this global system of injustice on a larger national scale. More than a decade after these events, the country appeared to have moved on being consumed by the internal fallout and ongoing tensions around Brexit. However, in 2020, the commemoration of enslavement again entered the public spotlight invigorated by the anti-racist protests in reaction to police violence in the United States and across the globe. More and more vocal groups like Black Lives Matter no longer accept the unchallenged adulation of slaveholders and those who profited from colonial exploitation in the form of statues and monuments. In Bristol protesters took matters into their own hands toppling the statue of Edward Colston and throwing it into the harbour. Similar acts can be witnessed worldwide. These demonstrations show how powerful cultural relics are in shaping notions of national belonging and how they continue to impact the devaluation of Black lives. This is why many believe such monuments should no longer have an uncontested place in the public sphere.

For the (now revived) debate on memorial culture and racism, the bicentenary of 2007 marked a turning point in Britain. In that context many politicians struggled to find the right tone to commemorate slavery and the transatlantic trade, specifically in relation to Britain's (historical and contemporary) self-understanding. Then Prime Minister Tony Blair 
was criticised for not offering a proper apology by circumventing the word "sorry", instead speaking only of "our deep sorrow". It seemed easier for Blair to delegate the cruelties of slavery to the far-away shores of the Caribbean and focus more on the abolitionist campaign at home. He also avoided the topic of possible reparations by emphasising the "better times of today", showing little understanding of the ongoing global economic repercussions that the trade in human beings and colonial exploitation in its aftermath have produced in the Global South. ${ }^{2}$ Moreover, the simplifying juxtaposition of the shameful slavers versus the noble abolitionists overlooks the fact that historically there was often a much subtler ameliorationist discourse at work which, while indeed becoming increasingly intolerant of chattel slavery during the eighteenth century, nonetheless dehumanised people of African descent. The tension of addressing Black agency and white benevolence is also palpable in The International Slavery Museum in Liverpool, opened in 2007. ${ }^{3}$ The exhibition puts great emphasis on Black contributions to the fight against slavery and educates visitors not only about slavery but also about West African culture. The celebratory endpoint of the display is a so-called Black Achievers Wall. Visitors to the museum and the museum's website are encouraged to interact with the exhibit by suggesting additions to the wall, be it "a sports person, a writer, an activist, a television personality — anyone just as long as they are inspirational". ${ }^{4}$ Yet outside the museum, more recently, the achievements of Black British inhabitants were once more violently overlooked. In April 2018, Theresa May was criticised heavily for the way in which children of the so-called Windrush generation, Caribbean commonwealth migrants who legally entered the country after World War II, had been targeted by immigration authorities. Several people, whose documentation did not meet official criteria through no fault of their own, were threatened with or actually deported, despite having lived in Britain for more than fifty years. In addition to Home Secretary Amber Rush having to ultimately resign, this scandal also forced the then Prime Minister to issue an apology that emphasised the valuable contribution of the Windrush generation and their rightful place in the United Kingdom. ${ }^{5}$ This discourse, in turn, seemed to rely heavily on conceptions of the "good migrant" who is never simply accepted as belonging and worthy of the protection of the nation state per se but continuously has to prove their "worth".

I am using these three seemingly divergent examples-Blair's failed apology for Britain's involvement in the slave trade, the celebratory "Black Achievers Wall" in The International Slavery Museum, and May's 
government's eventual attempts to appease in the so-called Windrush generation controversy by evoking the image of the "good migrant"-as entry points into my study of the literary archive of writing which made Blackness discursively compatible with Britishness. I want to show that the terms, the different tones, employed in shaping national belonging in canonical literary fiction and in the first written documents by Black Atlantic authors, a discourse that I describe as "familial feeling" in this book, have always relied on transnational entanglements. Individual words like "sorry" but also "inspirational", which figure prominently in the three short contemporary vignettes, demonstrate that the way Blackness and Britishness are interrelated is also a matter of tone.

Consequently, despite the prominence of the Windrush generation, entanglements between British and other cultures are not only the result of the migration following World War II but begin much earlier. The formation of the British nation in the seventeenth and eighteenth century was inextricably linked to the transatlantic economy and slavery in the Americas. The concomitant financial gain bolstered modern Great Britain's status as the most important imperial power of the time (cf. Walvin 2007: 8 ). However, within this formation slavery was not an uncontested status quo. The controversial public discourse ranged from the unapologetic pro-slavery plantocracy to the, often Evangelical, abolitionists, and positions in-between. While Britain's financial wealth still depended significantly on the slave trade, the campaign for abolition also became an unprecedented media success (cf. Wood 2002: 9). Gaining momentum in the late 1780s, the debate on the abolition of the slave trade was influential for the British enlightenment and the emergence of the middle class. Accordingly, in this book I look back at the historical archive of English literature, specifically at narrative texts by Black transatlantic authors and canonical British writers from the eighteenth to the mid-nineteenth century to discuss how ideas of familiarity, of becoming part of the nation, were navigated by variously positioned subjects. In the two main sections of this study, I trace a shift in discourses on familial feeling, from the eighteenth-century emphasis on moral sentiment and sentimentalism as the predominant mode in fiction to social reform and realism that was to become characteristic of Victorian writing. This also changed public discourse from focusing on abolition and the aftermath of slavery in the Caribbean to a reinvention of the British empire and its enlightened New Imperialism that was no longer built on enslaved labour but territorial expansion in Asia and Africa. It was in competition with several European 
powers in the second half of the nineteenth century when the British empire had, in fact, reached its greatest extent. Thus, the abolition of the slave trade in 1807 and the Indian Rebellion of 1857 are indicators of discursive turning points in these debates that mark the end dates of the two sections in this book.

This particular spatio-temporal framework of Familial Feeling, I argue, also promotes a reassessment of the so-called rise of the (British $)^{6}$ novel account that has been variously discussed ever since Ian Watt's eponymous path-breaking study in 1957. Reframed here as a story of entangled tonalities, considering both the generic aesthetic ideals underlying the novel form, understood first and foremost as prose writing that depicts realistic affective individualism, and notions of Englishness and Britishness as products of transatlantic negotiation. The rise of the novel can thus be related to a process by which modern Britishness is consolidated as inclusive of the formerly enslaved in the eighteenth century. This, however, gives way to greater colonial ambitions in the course of the nineteenth century. Accordingly, the novel form of writing prose that emerged in the eighteenth century and became more established in the nineteenth century modified the registers of how readers thought about families and belonging and who was included in communities of the familiar. In order to grasp these modified registers of familiarity in this book, I will discuss four different tonalities in the work of eight authors that shaped conceptions of the human in relation to the debates around British national identity, the abolition of slavery, and the emergence of the British empire, beginning with the foundational tone of Daniel Defoe and Olaudah Equiano, followed by the digressive tone of Ignatius Sancho and Laurence Sterne and the resisting tonality of Jane Austen and Robert Wedderburn and finally the consolidating tone of Charles Dickens and Mary Seacole. Literary scholar Sianne Ngai employs the concept of tone as a way "to account for the affective dimension of literature" (2007: 44), to bridge formal and political analysis of literary discourse, and I will return to this idea in explaining entangled tonalities in greater detail.

This project is admittedly ambitious. It operates on at least three different but interrelated levels. In concert with more recent approaches in the historiography of the British empire, I firstly hope to foster a view of British literature as part of a global network that can only be told as a story of entangled modernities. Such a temporal framing stands in contrast to the strong focus on the late nineteenth and twentieth century in postcolonial studies and the model of "writing back". Traditionally, English studies 
of the novel, on the one hand, concentrate on the aesthetic and narrative development of the genre or, owing to Edward Said's interventions that I discuss in greater detail in the chapter on Austen and Wedderburn, examine colonial influences on canonical sources (or, as a third independent branch of research, analyse the "new" global Anglophone literatures in the former colonies). In this study however, the literature of marginalised subjects is not to be simply added to the established canon. Rather, the focus is on the simultaneous and intertwined marginalised and hegemonic claim to literature as a transatlantic sphere of subjectification. Literature therefore functions as the medium of middle-class self-assertion and of the emotive access to subject status by those who have been excluded from the realm of the human, the "family of man", or, as Henry Louis Gates, Jr., has famously phrased it, "The slave wrote not primarily to demonstrate humane letters, but to demonstrate his or her own membership in the human community" (1988: 128). Simon Gikandi likewise argues: "culture became the most obvious form of social mobility and self-making in the century that invented the modern individual" (2011: 55). ${ }^{7}$ In his comprehensive study on Slavery and the Culture of Taste Gikandi elaborates:

In Britain as elsewhere in Europe, the promotion of a culture of sense and sensibility, of politeness and conduct operated as if the problem of enslavement belonged to distant reaches of empire far away from the domestic scene in which new identities were being constructed. (2011:90)

While the "humanising" function of literature that Gates and Gikandi describe seems immediately convincing, we should also direct more attention to the fact that the early Black Atlantic authors also engaged in aesthetically challenging forms thereby altering writing conventions and the tonality of Britishness. Thus, my transnational mapping of the rise of the British novel specifically concentrates on the ideal of the middle-class family and registers of familial feeling.

Hence, secondly, the title of the book, Familial Feeling, is explored, in Raymond Williams's terms, as a "structure of feeling" that organises and, on a more methodological level, challenges questions of empathy and reading/writing in relation to processes of inclusion and exclusion. The act of reading as empathic identification with someone else-accelerated by the technological revolutions, increased literacy, and faster distribution at the time-becomes crucial for the emotional register of the middle 
class. I aim to interrogate how this formation was always reliant on interaction with Others and cannot be framed as a linear progress narrative. ${ }^{8}$

Thirdly and finally, on a methodological level, my goal is to bring into dialogue the mainly separated spheres of (postclassical) approaches in (transatlantic) narrative studies, addressing aesthetic dimensions of literary tone and narrative identity formation, with those strands of affect theory that emphasise the political mobilisation of affect and (often negative) feeling, prevalent in postcolonial and queer theory as well as in African American studies, which I take up in more detail in the conclusion, dealing with contemporary memorial culture and the ethics of engaging with the archive of slavery. I thus advocate a continued permeability for cultural studies perspectives in literary studies instead of a re-canonisation in national literary studies.

Bringing into conjunction these diverse perspectives on familial feelings of Britishness, I argue, helps to systematically resituate the well-known texts by Defoe, Sterne, Austen, and Dickens and defamiliarise the established understanding of the rise of the novel. The similarities in political bearing and aesthetic choices, the entangled tonalities, regarding the topics of slavery and colonialism between the canonical authors and sources written by those whose lives have been shaped by transatlantic crossings, such as Equiano, Sancho, Wedderburn, and Seacole, are not considered extraordinary or in binary opposition, but rather part and parcel of the very rise of Britishness and its narratives. These texts are read side by side as part of a larger "family history"; together they construct, circumvent, contest, and consolidate the narrations of modern nation states and the emergence of a British literary canon. Before expanding on these ideas in the literary readings in the following four chapters, I will provide a more systematic historical and methodological contextualisation for the underlying premises of this book. For the remainder of this introduction, I first explain in greater detail what I call "familial feeling" in relation to the intertwined histories of modernity and slavery. I then discuss how this idea can be linked to and help reframe the "rise of the novel" account and finally suggest looking for "entangled tonalities" as a way to capture the dynamics between the British novel and early Black Atlantic writing. 


\section{Familial FeEling}

“The word 'family' can be used to mean many things, from the conjugal pair to the "family of man"", writes historian Lawrence Stone (1977: 21) in his classical substantial account of the modernisation of family life, The Family, Sex and Marriage in England, 1500-1800. It is specifically this flexibility of the term family which covers both the micro structure of societies as domestic units within one household as well as a much larger conception of belonging to the human race in general that I wish to evoke in the phrase "familial feeling". ${ }^{9}$ It purposely echoes the expression "familiar feeling" because the family, despite the vagueness of the concept itself, is referenced time and again as the locus of supposedly self-evident commonality. No social sphere, it seems, is as saturated with affects and regimes of feeling as kinship structures. They organise emotional belonging as well as social intelligibility and the accumulation of wealth. They are familiar to all of us.

Concurrent with Stone's family history in 1977, Raymond Williams, one of the founding figures of British cultural studies, considered the affective importance of cultural artefacts as part of a "structure of feeling". In contrast to the more static concept of ideology, Williams emphasises the emotional dimension in the emergence and shifts of social norms. This is his well-known definition:

We are talking about characteristic elements of impulse, restraint, and tone; specifically affective elements of consciousness and relationships: not feeling against thought, but thought as felt and feeling as thought: practical consciousness of a present kind, in a living and interrelating continuity. We are then defining these elements as a "structure": as a set, with specific internal relations, at once interlocking and in tension. [...] The idea of a structure of feeling can be specifically related to the evidence of forms and conventions $[\ldots]$ which, in art and literature, are often among the very first indications that such a new structure is forming. (1985 [1977]: 132-133)

These structures in turn can "support, elaborate, and consolidate the practice of empire" and affect coloniser and colonised as postcolonial critic Edward Said (1994: 14) has argued. Hence, the realm of what feels familiar is to a large degree reliant on how emotional belonging is imagined in art and literature. Familial feeling in this book then refers to the ways in which "the family" and "familiarity" are overlapping spheres. This is also one of the reasons why the notion of the family is especially attractive for 
those excluded from the realm of the human as a means to claim inclusion into both the larger "family of man" and the micro level of the nuclear family. The family is where the demarcation between self and Other is challenged. The Caribbean plantation, for instance, becomes the physical space in which interracial sexualised violence alters notions of who belongs to Britain. This debate will be addressed in the chapter on Austen and Wedderburn.

Stone describes in greater detail the processes that led to the modern family unit becoming the predominant form of living together in Europe. He recounts this development as a change from what he calls the "restricted patriarchal nuclear family" to the "closed domesticated nuclear family" which in Britain evolved in the late seventeenth century and predominated in the eighteenth. "This was the decisive shift, for this new type of family was the product of the rise of Affective Individualism. It was a family organized around the principle of personal autonomy, and bound together by strong affective ties" (1977: 7). In more than one respect, Britain pioneered the development of this middle-class family ideal. Earlier than in any other European state the so-called industrial revolution (and the concomitant urbanisation) gave rise to smaller family units and a rigid class system, as Friedrich Engels (2010 [1884]) outlined not by coincidence in relation to England in 1884 in The Origin of the Family, Private Property and the State. ${ }^{10}$ The modern individual then is conceptualised as autonomous and social at the same time.

So, while the nuclear (bourgeois) family can be understood as the epitome of modern belonging, it also becomes increasingly regulatory with respect to gendered, racialised, and sexualised norms, as Michel Foucault (1998 [1976]) has famously delineated in what he called the shift from the "deployment of alliance" to the "deployment of sexuality", which from the eighteenth century onward complemented the former. ${ }^{11}$ This creates ambivalence in the sense that the family can be considered to be both inclusionary and exclusionary. Metaphorically, the variously gendered family relations are extended to the very state itself in phrases such as "fatherland" or the "mother country". ${ }^{12}$ Accordingly, the conception of modern nation states as "imagined communities" in the eighteenth century superseded earlier systems of religious community and dynastic realm, as Benedict Anderson has described in his well-known work of the same name. Anderson stresses the importance of newspapers and novels, or more generally "print-capitalism" in this process (1991: 9-36; cf. also Bhabha 1990). ${ }^{13}$ Consequently, constructions of familial feeling and the 
rise of print culture need to be considered in unison to understand the shifts from the debate on abolition in the eighteenth century to colonial expansion in the nineteenth century. These modifications of regimes of familial feeling, I argue, can be described as gradual changes in emphasis from moral sentiment to social reform and from sympathy to charity.

In The Navigation of Feeling, William Reddy explains:

Scholars working on the eighteenth and nineteenth centuries $[\ldots]$ have begun to trace out the rise and fall of an emotional revolution of the past, called "sentimentalism," or the "cult of sensibility"—a loosely organized set of impulses that played a role in cultural currents as diverse as Methodism, antislavery agitation, the rise of the novel, the French Revolution (including the Terror), and the birth of Romanticism. (2001: $\mathrm{x}$ )

The modern emphasis on sentimental feeling seems connected from the outset to both literary aesthetic developments (the rise of the novel, Romanticism) and political upheaval (anti-slavery agitation and the French Revolution/terror). In this understanding, literature tests the limits of acceptable subjects and objects of emotional attachment. Some examples of eighteenth-century sentimentalism, specifically novels like Henry Mackenzie's The Man of Feeling (2009 [1771]), draw a fair amount of ridicule regarding the many tears shed on their pages already from contemporary readers and even more so from later Victorian writers (cf. Todd 1986: 141-146). ${ }^{14}$ By now there is a well-established field of scholarship that deals specifically with sentimental fiction and slavery/abolition. Especially noteworthy in the British context are Markman Ellis's The Politics of Sensibility. Race, Gender and Commerce in the Sentimental Novel (1996), Brycchan Carey's British Abolitionism and the Rhetoric of Sensibility (2005), Lynn Festa's Sentimental Figures of Empire in Eighteenth-Century Britain and France (2006) as well as Ramesh Mallipeddi's Spectacular Suffering. Witnessing Slavery in the EighteenthCentury British Atlantic (2016). ${ }^{15}$ These studies are valuable foundations for my readings, which I hope to complement by emphasising global entanglements and by discussing how the sentimental rhetoric extends into a longer history of the familiar/self as well as the strange/Other in Victorian fiction (and eventually even into contemporary efforts to commemorate the abolition of slavery in Britain).

So rather than focus exclusively on the mode of literary sentimentalism, I am more interested in how the selected writers shift the tone of 
representing self and Other in varying familial registers. Beginning with the foundational tone of claiming the status of a self-reflexive modern subject in Defoe and Equiano's writings, I then juxtapose the already playful mocking and digressive style of the sentimental men of letters Sancho and Sterne. Increasingly, familial feeling includes notions of terror and unrespectability in the aftermath of the terror of the 1790s and the abolition of the slave trade in the Caribbean, which Wedderburn's writings that I read with Austen's Mansfield Park represent. We again witness a more pronounced demarcation of Britishness in relation to both the United States and the colonies in the Victorian writing of Dickens and Seacole which can be characterised as consolidating the new imperial ambitions of the nation. So, while I do look at the "development" of novelistic writing, I aim to do so by focusing on transnational interaction as well as challenging the narrative of liberal progress.

Regarding the very concept and term enlightenment, historian Sebastian Conrad suggests that "it is less instructive to search for alleged origins-European or otherwise-than to focus on the global conditions and interactions in which the 'Enlightenment' emerged" (2012: 1009) and proposes to pursue a "long history of Enlightenment" (2012: 1015). He argues:

[T]hinking in stages was one of the ways in which eighteenth-century Enlightenment thinkers translated cultural difference into a language of progress. But while this idea coexisted with other notions of being "enlightened"-the progress of reason, the public sphere, secular world views-by the late nineteenth century, Enlightenment was increasingly inserted into a narrative of evolutionism and the advance of civilization. It was thus transformed from a process into a currency-some had more of it, and some needed tutors to give it to them. (2012: 1019)

In line with more and more eighteenth-century studies scholars, like Srinivas Aravamudan (1999) and Felicity Nussbaum (2005), Daniel Carey and Lynn Festa also critique a uniform understanding of Enlightenment (writ large) "into a kind of shorthand notation for a group of familiar abstractions: rationalism, universalism, equality, human rights, and science" (2009: 11) and in the introduction to their edited volume The Postcolonial Enlightenment call on literary critics to "make both centre and periphery plural" to "recognize multiple points of entry into discourses of Enlightenment as well as the possibility of alternative genealogies and 
teleologies" (2009: 24). Such an extension of the postcolonial framework to include the rise of modernity already in the eighteenth century helps bring into closer focus the entanglement of modernity with transatlantic slavery and colonialism, to divert "the otherwise frictionless circulation of the eighteenth century to itself as Eurocentric romance" (Aravamudan 1999: 329). Following these thinkers, I want to trace a "long history" of familial feeling in relation to the rise of the British novel. Hence, the two sections, demarcating writing before and after the 1807 British abolition of the slave trade, should not be understood as standing in stark opposition or marking a linear progress narrative but rather be aligned with Conrad's account of an enlightenment continuum. As part of this process, novelistic conventions also take stronger hold. ${ }^{16}$ Accordingly, we can observe a modification from sentimental to domestic fiction, ${ }^{17}$ which becomes reliant, again in Conrad's terms, gradually on a nationalistic "narrative of evolutionism and the advance of civilization". ${ }^{18}$

Let me contextualise these literary developments further in relation to the history of the slave trade. Obviously, it is predominantly work coming out of the academic discipline of history that has offered productive attempts to read European history as always already in relation to colonialism and the triangular slave trade. These approaches are linked to labels such as connected or entangled histories as well as histoire croisée and transatlantic $^{19}$ history or modernism (cf. Beckles 1997; Conrad 2012; Conrad et al. 2013; Werner and Zimmermann 2006). ${ }^{20}$ Given the limited first-hand accounts of the colonised and enslaved, however, alternative methodologies come into play in these historiographic accounts. ${ }^{21}$ One angle is the attempt to write counter-histories, often incorporating fictional sources. In their influential transatlantic "history from below" The Many-Headed Hydra, Peter Linebaugh and Marcus Rediker, for instance, reconstruct the "lost history" of a "multiethnic class" (cf. 2000: 6) focusing on rebellious inter-racial alliances. In a similar but differently framed attempt, linking eighteenth-century accounts of slavery to more contemporary history and what he calls "the long twentieth century" Ian Baucom (2005: 17) discusses the Zong massacre 22 and the numerous ways in which this history and the spectre of the dead still "haunt" modern capitalist societies. Given the many fictionalised versions of the event, including J.M.W. Turner's 1840 painting "Slavers Throwing overboard the Dead and Dying-Typhoon coming on" (later simply called "The Slave Ship"), he too turns to artistic imagination in his Specters of the Atlantic. ${ }^{23}$ One way to reconstruct transatlantic history then is the recourse to neglected 
sources, trying to "give voice" to the marginalised. However, both these important historical interventions remain committed to a project of counter rather than truly entangled histories which would, I argue, also account for more uncomfortable aspects of collusion, for instance.

Susan Buck-Morss' equally influential Hegel, Haiti and Universal History is one of the most persuasive interventions into the intellectual history of the West to date precisely because she highlights the reciprocity of the West and "the rest" in ways that I would see more closely aligned with an entangled understanding of European modernity (rather than a counter-history). She investigates how enlightenment thought coincides with the systematic mass subjugation of human beings and calls slavery the "root metaphor of Western political philosophy" (2009: 21). Buck-Morss focuses on German philosopher Georg Wilhelm Friedrich Hegel and his potential knowledge of the Haitian Revolution interlinking this uprising with the French Revolution, to "consider Haiti not as the victim of Europe, but as an agent in Europe's construction" (2009: 80). Also taking Hegel's philosophy as a starting point, Paul Gilroy's widely applied concept of the Black Atlantic ${ }^{24}$ (1993) still offers one of the most fruitful points of departure in theorising modern subjectivity in relation to the violence of transatlantic enslavement and influences my framing of Black writing as integral to the foundation of British conceptions of self and Other. Gilroy criticises Hegel's "dialectic of intersubjective dependency and recognition" (Gilroy 1993: 68). ${ }^{25}$ The Hegelian slave, or bondsman to be more precise, prefers bondage rather than death (cf. Hegel 1970 [1807]: 113-120). In narratives of real slavery, however, "positive preference for death rather than continued servitude" undermines Hegel's allegory (Gilroy 1993: 68), apparent in texts like Equiano's narrative, a notion to which I will come back in greater detail in my reading. In such a global understanding of the history of modernity then the metaphors of bondage/slavery and Europe's emancipation into an enlightened state clash violently with the material reality of chattel slavery. At a time when the so-called enlightened subject is finding its voice, legally enslaved people were not "inferior subjects" but "a special kind of property" (Gikandi 2011: 91). By turning to entanglement, I want to emphasise the very paradoxes of European modernity that is violently exclusionary but also becomes a space of potential or imaginary radical inclusivity.

In Britain, slavery fuelled middle-class financial wealth, the rise of the banks, especially in port cities like Liverpool and Bristol, while chattel slavery was safely pushed out of sight, as historian James Walvin argues: 
For more than a century and a half, from the founding of British Caribbean slavery, the British had enjoyed the expanding wealth of their slave colonies without troubling themselves too much about the inhumanities and immoralities which underpinned the system. (2007: 99)

This ignorance towards the realities of chattel slavery also influenced how Black people were perceived at the time. In her popular historical study Black London: Life before Emancipation, Gretchen Gerzina estimates that by 1768 around 15,000 Black people lived in London (with a total population of about 676,250) (1995: 5). However, Black British subjectseven if in servitude-were often more fashionable "house servants" rather than slaves. Other members of the predominantly male population worked as musicians and sailors, and occasionally African royalty was sent to be educated abroad. ${ }^{26}$ Hence, while there is a growing visible Black presence in Britain, the eventually scandalised "horrors of slavery" are connected primarily to the Americas, not to British soil in the public imagination.

Despite these distancing mechanisms regarding the day-to-day realities of slavery, there is growing awareness of and public debate on the crass incongruity of the philosophical ideals of enlightenment thinking and the lived reality of slavery which does not remain unchallenged in the second half of the eighteenth century, neither in the colonies (as the history of slave uprisings, such as Tacky's Rebellion in Jamaica in 1760, underlines), nor in Britain. It is interesting to note, however, that in the West, it is not the rational secularised elite but often members of the dissenting Protestant sects and Evangelicals who became active first in the fight to end slavery (cf. Sandiford 1988: 52). Accordingly, there is a twenty-year period of campaigning for the abolition of the slave trade beginning in the 1790s when William Wilberforce brought several unsuccessful petitions before Parliament. ${ }^{27}$ In this context, literary texts contributed the dimension of feeling as one important indicator of modern subjectivity - to feel pain and to empathise with others become crucial for the notion of the enlightened subject and eventually for the abolitionist campaign.

Nonetheless, what exactly led to the eventual abolition of slavery in Britain is disputed among historians today. Walvin (2007: 99, 106-123), for instance, links the success of the British campaign for abolition to the rise of free trade, which promised to be more successful financially than the more and more risky triangular slave trade, rather than interpreting it as a moral triumph of the abolitionists (cf. also Brown 2006). ${ }^{28}$ Charlotte Sussman (2000), too, emphasises economic motives for the increasing 
British criticism of the slave trade..$^{29}$ But the changing public discourse cannot be linked to economic factors solely.

Legally, one important milestone in the fight for abolition was, as widely noted, the Somerset case of 1772 which preceded the mentioned infamous 1781 first Zong case. The degradation of human beings to property was challenged when the fugitive slave James Somerset won his case put forward by Granville Sharp before the Chief Justice, William Murray, First Earl of Mansfield and-being granted a writ of habeas corpus—could not be re-sold into West Indian slavery since he had already entered British soil (cf. e.g. B. Carey 2005: 175; Sandiford 1988: 66). ${ }^{30}$ This is seen by many as the beginning of Britain's paradoxical exceptional standing on outlawing slavery at home while still profiting financially from its plantations abroad for at least the following sixty years (cf. Swaminathan 2009: 86-100). Buck-Morss argues that a distinct spatial ordering is at work here. 'The Somerset case defined slavery as essentially 'un-British,' an 'alien intrusion' which could be tolerated at best, as an unfortunate part of the commercial and colonial 'other-world"' (2009: 92). Despite the growing bleak working conditions in urban factories, Britain was demarcated as the "free world" (2009: 100) and Buck-Morss classifies the factory as an "extension of the colonial system" at home (2009: 102). This underscores how the domestic and the colonial sphere interact, continuously rivalling for public attention-a concern in almost all the literary texts discussed, especially in Dickens's later Victorian writing.

These trials about the "human" status of the enslaved predate the legal battle for women's suffrage. Nevertheless, one can also detect connections that continue well into the nineteenth century as I will lay out. Here, too, we see that despite the fundamental subjugation of women, enlightenment discourse extended a paradoxical promise of inclusivity. While women were far from enjoying equal rights, upper and middle-class white women received more access to the political sphere in the eighteenth century. In the colonies, many white women participated in forms of domination-often being able to exercise such power for the first time. Others, in turn, expressed political agency by lobbying for the abolition of slavery (while being denied the status as citizens in Britain) (cf. Ferguson 1992; Woodard 1999: 68). But regardless of white women's visible commitment to abolition, this political dedication was often not automatically sutured to the feminist demands of women's suffrage which, despite the 1792 publication of $A$ Vindication of the Rights of Woman by Mary Wollstonecraft (1992 [1792]), only gained momentum at the turn of the nineteenth to 
the twentieth century. Quite on the contrary, many (Evangelical) female abolitionists opposed the more radical demand for women's rights and emphasised women's role as virtuous helpmeets of their husbands. Abolitionist poet Hannah More, for example, expressed moral outrage over the lewd and unchristian behaviour in the colonies that threatened notions of modesty (cf. Ferguson 1992: 9, 146-147). The fact that the male British planter class produced offspring with enslaved women challenged not only boundaries of Christian morality, it also led to constellations in which the father literally and legally became the "owner" of his children, a taboo that is hinted at in Austen's text and explicit in Wedderburn's recalcitrant letters to his Scottish family.

While the emerging nineteenth-century discourse of scientific racism turns this into a narrative of threatening "contamination" of the "English race", eighteenth-century abolitionist discourse relies more strongly on a supposed female sensibility that can extend into the plantocracy in the Caribbean and thereby help keep "order" in the British domestic sphere. Sussman explains this in the following terms:

In abolitionist pamphlets, $[\ldots]$ active female virtue is conjoined to a kind of national sensibility, a female anxiety [...]. The compassion of British women symbolizes a specific national identity—a quality that distinguishes England from the rest of the world. [...] Abolitionist rhetoric thus consciously calls on female sensibility to safeguard the home from colonial contamination, to preserve that home as a symbol of a purified English identity, and thus to ensure that the domestic sphere remains distinct from the colonial arena. (2000: 126)

Thus, the "progressive" politics of white female abolitionists also fed into moral conceptions of national purity imagined as increasingly endangered in Britain's colonial involvement. Abolitionist writing (which included texts by Black and white authors) therefore should be contextualised as a highly ambivalent political project. Building on these historical and political analyses my interest is specifically in how these discourses shaped the aesthetic tonalities of creating familial feeling in prose narratives of the time, which, in turn, need to be sutured to the larger philosophical debate on feeling and sentiment.

In relation to the eighteenth-century moral philosophy of the so-called Scottish enlightenment thinkers the concept of sympathy is central. Helga Schwalm underlines the double meaning of sympathy as a communication 
of sentiments (feeling) and sentiments as the moral foundation of understanding an "Other" (cf. Schwalm 2007: 18; cf. also Neumann and Schmidt-Haberkamp 2015). It is specifically Adam Smith's Theory of Moral Sentiments that is relevant in this context as he proposes sympathy as a process of imagining ourselves as others, which he calls "fellowfeeling" (2009 [1759]: 14). Ellis further explains: "Smith's account of sympathy has the logic of Burke's sublime, in that there is a fundamental discontinuity between the quality of feeling of the viewer and the sufferer of pain or fear" (1996: 13). As a result, in literature, we can observe a proliferation of sentimental and tearful displays of pity and compassion, both aspects of sympathy in Smith's understanding, which goes hand in hand with a growth and the increasing institutionalisation of philanthropy (cf. Ellis 1996: 14). Similarly, Brycchan Carey argues that the discourses of abolition and sentimentality have shaped a specific "sentimental rhetoric" whereby sympathy is understood as a means to shed light on suffering (2005: 2).

Abolitionist discourse therefore scandalised the bodily and emotional anguish of enslaved Africans as a means to generate momentum against the slave trade (which was, we must remember, not palpably present in the daily lives of many Britons, even those who held considerable financial interests in Caribbean plantations). As Simon Strick (2014) has argued, the very capacity to feel pain became a form of cultural capital that enslaved Africans supposedly lacked altogether. The enslaved were reduced to mere bodies, which turned them into the "ideal" workforce for the hard labour on the plantations. Hence, the emphasis on the physical pain of slaves, on cruel bodily punishments and mutilations, as well as the severe emotional scarring that the severing of family ties caused, functions as both an "appeal to common humanity" and "evidence of the capabilities of Africans" (Innes 2002: 17); and in this endeavour "new literary forms and new narrative and poetic techniques emerged" as Lyn Innes (2002: 4) argues. Sympathy is thus interrelated with the arts and the power to imagine oneself in the position of another, which longer prose fiction and the novel specifically catered to. Ellis accordingly links the rise of sentimental fiction and the political debate on the abolition of slavery aesthetically. ${ }^{31}$ He argues,

The paradox of sentimentalism, simply stated, is that these novels are the site of considerable political debate and that this is so despite and because of the extraordinary texture of the novels, with their focus on romantic-love plots, 
their devotion to the passions and the rhetoric of tears and blushes, and their fragmentary and digressive narrative. (1996:4)

In other words, while the emotionalising and digressive style of sentimental fiction ${ }^{32}$ seems at first glance at odds with the highly politicised and serious topics these texts address (cf. Festa 2006: 2), the depictions of suffering and sympathetic feeling are related. Indeed, there is a specific eighteenth-century aesthetic indulgence played out in sentimental fiction that can be understood as a means to establish oneself as a particularly emotionally sophisticated subject (cf. also Keymer 2005). This aspect will come under closer scrutiny in the chapter on Sterne and Sancho who communicate, despite their very different positionalities, similarly as sentimental men of letters. Accordingly, Ellis states, "Reading sentimental fiction, then, was to be an improving experience, refining the manners by exercising the ability to feel for others" (1996: 17). This then gestures towards the paradox of sympathy as reproducing regulating mechanisms in its reliance on objects of pathos and the spectacle of the suffering slave, as Amit Rai (2002: xi) argues in his book Rule of Sympathy. ${ }^{33} \mathrm{He}$ explains:

[I]n the colonial ordering of the West Indies and India, paternalism as a model, the family as an object, and "domestic affection" as an instrument were all central to the practices of governing populations. [...] Sympathy was both a model and instrument of governmentality. (Rai 2002: 8-9)

Put differently, in the discourse on sympathy, those aspects that Stone considers foundational of modern family relations and which he calls affective individualism can go hand in hand with a Foucauldian notion of governmentality that increasingly understands colonial relations as family relations. Again, Rai's explications are helpful:

[F]or eighteenth-century moral philosophers, the family was the preeminent work space for the functioning of sympathy. As it became a vehicle for new pedagogies of control and the elaboration of citizenship [...]: The sympathetic relation, as the first of all domestic affections, became a model and an instrument for a newly atomizing class-society and a rapidly consolidating empire. Finally, the metaphor of family also became part of counterdiscourses, critiques, and strategic displacements. (2002: 35)

As a result, current scholarship is critical of the conflation of sentimentalism with progressive humanitarianism (cf. Boulukos 2013) and highlights 
questions of paternalism but also counter-hegemonic agency. ${ }^{34}$ The most famous and central visual representation of this paradoxical effect of sympathy is the sentimental emotionalising image of the kneeling shackled slave on the Wedgwood medallion of the British Anti-Slavery Society, pleading "Am I Not a Man and a Brother?", which became a popular embellishment of crockery and was worn as a fashion accessory by women who supported abolition (cf. Dabydeen 2011; Festa 2006: 164-171). On the one hand, it depicts a subservient man in need of help. On the other hand, this Black man becomes part of the "family of man" for the first time (and later a female equivalent was produced, too). From a contemporary perspective, this image is criticised precisely because such representations cater to a supposedly enlightened benevolent white audience and hardly leave room for Black agency. Festa fittingly calls this a "trope of redundant personification" since it "recreates the humanity of someone who is already human" and therefore "exposes the way sentimental personification dehumanizes the very figure it animates" (2006: 12) while simultaneously bestowing "affective distinction" (2006: 187) to those who express sympathy. The humanity of the enslaved is not taken for granted; it becomes the subservient question addressed to a benevolent audience that has the power to include or exclude the objects of its sympathy into the realm of the familiar.

With increasing fears of the more radical terror of the revolutionary uprisings at the end of the eighteenth century, abolitionist discourse showed docile slaves who patiently waited (or begged) to be freed by their masters rather than engage in more violent protest against slavery which was a common reality in the Caribbean slave revolts. In this sense, these images actually produce overlap with some of the assumptions around the figuration of the "grateful slave" that George Boulukos has analysed comprehensively, and which originated in pro-slavery publications. Unthreatening sentimentalised accounts of slavery promoted a more moderate form of amelioration rather than abolitionist discourse that cannot simply be separated into politically progressive versus conservative: Amelioration became a "'moderate' $[\ldots]$ middle ground claimed by both abolitionists and slave owners. Amelioration was attractive to plantation owners not only because it imagined slaves happily embracing their slavery, but also because it staved off a public demand for emancipation" (Boulukos 2006: 362). ${ }^{35}$ Boulukos thus identifies benevolence as the central marker of power that becomes prevalent first in pro-slavery and later abolitionist discourse (cf. 2008: 21). Importantly, the image of familial 
care is evoked here once more in "the pro-slavery vision of a familial relationship between benevolent paternalist masters and faithful dependant slaves" (Boulukos 2008: 37). In a similar understanding, Festa argues that the "sentimental feeling self is thus the Janus face of the Enlightenment rational subject" (2006: 4). While eighteenth-century philosophical discourses on sympathy challenge the boundary between self and Other, the aesthetics of sentimentality, Festa contends, stabilises the dichotomy of the subjects and objects of feeling and by extension imperial aspirations (2006: 6-8).

Nevertheless, while sympathy elicits uncomfortable questions about the agency of the suffering Other, it is also a marker of social distinction as a feeling/sympathetic modern subject that increasingly Black writing subjects like Equiano and Sancho claim by employing this rhetoric themselves. In this way the adoption of such sentimental aesthetics then can also bear subversive potential and the representation of Black suffering remains ambivalent. In accordance, Sussman describes the oscillation between disgust and sentiment in eighteenth-century representations of colonial subjects as instants of possible disruption of hegemonic frameworks. She suggests "reading moments of uncontrollable affect not as monuments to the crushing power of a racist ideology, but as places where the balance of colonial power is revealed to be unstable" (2000: 17). Therefore, rather than focus straightforwardly on the political implications of sympathy overburdening the racialised body with affect, I will interrogate the ambivalent aesthetics of creating familiarity via sympathy not limited to the literary style of sentimentalism (which the scholars cited in this section have explored so fruitfully).

Barnes succinctly states that "sympathy is both the expression of familiarity and the vehicle through which familiarity is created" (Barnes 1997: 2). We can notice this idea already in Smith's original conception of how sympathy works. He writes that "my imagination is more ductile, and more readily assumes $[\ldots]$ the shape and configuration of the imaginations of those with whom I am familiar" (2009 [1759]: 37). Familial feeling then is both inclusionary as well as exclusionary, as Barnes argues conclusively: "Whatever character(istic)s cannot be made to conform to the family image must remain excluded from sympathy, while those that are included must be represented in such a way that they prove familiar and thus identifiable" (1997: 97). However, Barnes, in general seems to overemphasise the need for familiar similarity in objects of sympathy I would argue. First of all, the fact that a subject can sympathise with someone who 
is clearly marked as different such as "the slave" shows a form of triumphant compassion that can help distinguish oneself from those who are less enlightened such as "the slaveowner" (often marked as unchristian). Thus, sympathy is a marker of distinction that gains relevance also in the growing transatlantic public sphere. One effect of the early phase of protest and the eventual success of the abolitionist campaign with the abolition of the slave trade in $1807^{36}$ and the eventual passing of the Slavery Abolition Act of 1833 then was that it enabled the British to imagine themselves as exceptionally modern and progressive in their renunciation of slavery. Christopher Brown convincingly describes this as an investment in "moral capital" (2006) as a reaction to the American Revolution and the lost influence in the Americas. British abolitionism is set against the United States' deplored holding on to the-as it was called then"peculiar institution" of slavery which was abolished in the United States only some thirty years later with the passing of the Thirteenth Amendment at the close of the Civil War in $1865 .^{37}$

Consequently, expressions of feeling can also promote a form of national demarcation that comes into play in Britain's self-conception of moral superiority in relation to what is perceived as the United States's belated abolition of slavery. ${ }^{38}$ So, while there must be a certain kind of fraternal similarity, and here I agree with Barnes, as "man and brother" to evoke familial feeling, markers of difference between the subject and object of sympathy are never entirely elided. Especially in forms of rhetoric that emphasise a (British) moral exceptionalism in degree of emotional responsiveness, it serves to create familiarity but also hierarchical distinction from those who "feel" less. Britishness here becomes an attractive vessel to claim familiarity with the formerly enslaved who should not be reduced to passive objects in this discourse.

Accordingly, this supposed moral superiority also influenced the transatlantic reception of Britain and turned it into a centre of attraction for African American thinkers which prompts Elisa Tamarkin to speak of "Black Anglophilia". ${ }^{39}$ Tamarkin describes the travels of Black intellectuals such as Frederick Douglass and Samuel Ringgold Ward in the nineteenth century to the United Kingdom as comparable to the European grand tour of the male English elite in the eighteenth century (cf. Buzard 2002) and often a first step to claim the status of "citizen of the world" (Tamarkin 2002: 455, 460). The formerly enslaved cross the Atlantic in the reverse direction of their forbearers and, as Tamarkin (2002: 473) contends, thus champion a modern transnational cosmopolitan identity that understands 
Britishness as culturally progressive. ${ }^{40}$ The stylised sentimentality of the eighteenth century morphs into more realistic depictions of interiority and familial feeling that Black authors also partake in.

Historian John Tosh characterises the 1830s and 1840s in Britain as consolidating the ideal of the home as the site of emotional belonging. He writes, "The Victorian middle-class domestic unit represented the final and most decisive stage in the long process whereby the rationale of the Western family shifted from being primarily economic to become sentimental and emotional" (Tosh 1999: 13). In this process, the Victorian nove ${ }^{41}$ is firmly established as the emotive vehicle for familial feeling:

Domesticity in this sense was essentially a nineteenth-century invention. One can go further and say that it was an integral aspect of modernity: socially it was inconceivable without large-scale urbanization; culturally it was one of the most important expressions of that awareness of individual interiority which had developed since the Enlightenment. Practised first and most intensively by the bourgeoisie, domesticity became the talisman of bourgeois culture, particularly in painting and novels. (Tosh 1999: 4)

In a similar vein, historian Ute Frevert speaks of the development of a "bürgerlichen Gefühlshabitus" (2011: 14). According to Frevert, the conception of this habitus of bourgeois emotion is reliant on the attribution of the "realness" / authenticity of feelings and sympathy (in contrast to the false feeling and pretence of the aristocracy that is sometimes associated with the literary style of sentimentalism) and the working classes and nonEuropean societies who supposedly lacked feeling and refinement altogether (cf. 2011: 14). Sympathy and sensibility now become middle-class virtues. But Frevert to a certain degree reinstates these borders as fixed. Looking at early Black Atlantic writing, we see how those subjects who are supposedly excluded from these norms do cite them-even before they are fully recognised citizens. Modern subjectivity as the capacity to express "authentic" feeling in writing thus is highly contested in the transnational public sphere ${ }^{42}$ I will argue.

While there are many consistencies and continuities with earlier eighteenth-century sentimentalism, increasingly the discourse shifts from a debate about who has the capacity to feel to begin with to a focus on refined emotionality as a form of class and civilisational distinction (much like the shift that Conrad identified in relation to the idea of enlightenment from process to currency). The question now no longer is if Africans 
and their descendants are human (in the sense that they possess the same feelings as Europeans), now there is concern about how they should be governed as British colonial subjects (for instance, in relation to the question of African resettlement or the debate whether mixed-race subjects can be considered British). Consequently, hegemonic expressions of emotionality in the literary realm shift as well: We no longer read of the abundant tears and boundless expression of affection, but witness a display of controlled feeling that takes centre stage, as Gesa Stedman (2002) highlights. ${ }^{43}$ This measured presentation of emotion was considered crucial for the emergence of the middle-class habitus in Victorian England. Stedman identifies "affection, feeling, emotion, passion, sensibility and sentiment" (2002: 25) as the most common "emotion words" in the nineteenth century. So, while there is not necessarily a radically new vocabulary of feeling, there is indeed a different emphasis on degree, which corresponds to the generic stabilisation of the novel ${ }^{44}$ and the predominance of domestic fiction. This, in turn, can be connected to a reemphasis on gendered difference which the men of feeling had disrupted to a certain degree.

While women have always also managed family affairs, Nancy Armstrong describes the naturalisation of the gendered middle-class division of labour into the figurations of the new "domestic woman" versus the "economic man" (cf. 1987: 59). This gendered order however is less dependent on the supposedly separate private and public spheres, as Tosh (2004) contends, than on the distinction between citizens and non-citizens. He elaborates that middle-class men's prerogative was not only the access to the public sphere, but also a distinctly male role of caretaker as a "man of character" $(2004: 76,197)$ within the realm of the private. These duties extended mainly to economically dependent women and children. ${ }^{45}$ Consequently, rather than debate sympathy as a philosophical capacity, there is now increasing concern about who is worthy of sympathy as in the professionalisation of charities, which fosters a distinction between the "deserving" and "underserving" poor, for instance. In this way, the family becomes the locus of governmental control which Foucault (2008) famously described as "biopolitics".

These ideas were also extended into the colonies where, as is much noted (for instance by Rai 2002), the supposedly "childlike" natives were conceptualised as requiring English "parental" guidance. In this way, progress and modernity become products of an ethos of familial care which requires those who are not (yet) modern. Thus, through colonial expansion and emigration, working-class men and women were included 
more and more into the promise of (class) mobility since it was first and foremost the so-called surplus men and women (McClintock 1995: 238) who left England to "conquer" a bourgeois identity elsewhere. In accordance with this growing emphasis on rule abroad and self-regulation at home, the civilisational concerns with "family hygiene" and the threat of "racial purity" are also increasingly framed as a form of competition between the colonial sphere and the working class in Britain as was noted earlier. $^{46}$

This courting public attention is thus not entirely new but a sign of the shifting discourse. Put forward initially by pro-slavery writers of the late eighteenth century who tried to divert attention away from the harsh working conditions of the enslaved in the Caribbean by suggesting that there was hardly any difference between the work on the plantations and the "sufferings of the British poor, in particular, miners and child chimney sweeps" (B. Carey 2005: 15), this playing off of one form of oppression against another returns with a vengeance in Victorian depictions of the working classes, as in the pitiful street urchin Jo in Dickens's Bleak House which I discuss in my reading of the novel in Chap. 5. The "Chartist critique of 'white slavery' in England" (Rai 2002: 121) is reliant on symbolically black figures of neglected whiteness. However, interestingly, this construction now appears in "progressive" discourse, too. ${ }^{47}$ So again, I am not suggesting a radical break between eighteenth-century sentimentalism and the nineteenth-century novel. Rather I am interested in a consolidation and suturing of ideas of belonging that are tied to notions of familiarity which is no longer philosophically framed only as "fellow-feeling" but displayed in modes of regulating those who belong to a specific national "imagined community".

While the "authenticity" of Black authorship continues to be contested, the rise (or consolidation) of the novel, I argue, enabled marginalised subjects to claim different literary registers or tonalities of familiarity (as is to be argued in relation to Wedderburn's resisting voice in contrast to Seacole's more consolidating tone, for instance). Conversely, the novels of Austen and Dickens include references to slavery to both test and buttress notions of the British family. This is a more complicated Bakhtinian dialogue than radical versus conservative family narratives; the authors at the centre often emphasise the complicated gendered implications of the bourgeois novel (Austen and Dickens) while Black Atlantic authors sought to implement their position within the British family by constructing different Others (Seacole's reference to colonial and US-American Others, 
for example). Following the 1857 so-called Indian Mutiny, Britain drastically professionalises colonial ordering as familial control. I end my study with texts then which can be understood as pointing in the direction of a consolidation of colonial expansion in the second half of the nineteenth century when Britain enters the phase of the so-called New Imperialism (cf. Hobsbawm 1989; Swaminathan 2009: 217). Nonetheless, the gendered social order was never uncontested. The numerous efforts to reform inheritance and marriage law as well as resistances to colonial rule in the nineteenth century are results of these social processes that turned the family into the central modern social regulatory unit and arena of conflicting powers. ${ }^{48}$ As laid out in this historical overview, the dissemination of feeling through print publications, in general, and the emplotment of national belonging in the ever more popular novel, in particular, evoked an inclusionary promise into a new form of familiarity that my title "familial feeling" alludes to. The readership of these texts also came to include populations outside the bourgeois metropolitan elite. This finally brings me to the link between familial feeling and the rise of the novel as a specific aesthetic development that is often told purely within a national framework and detached from the global historical and political developments I have presented so far.

For this purpose, let me return once more to family historian Lawrence Stone's terms. Stone sees affect—or, in accordance with terminology used in affect theory ${ }^{49}$ today, we would rather speak of feeling-less as the expression of a unique modern capacity of middle-class men and women, but as an effect of a media-specific form of communication that is closely related to the development of the novel. He writes,

There was rapidly growing emphasis on the novel, which itself evolved from a picaresque narrative of external adventures, like Robinson Crusoe, to an in-depth discussion of love, property and marriage, which were the dominant themes of the genre from Samuel Richardson to Jane Austen. There was also a substantial increase in literacy and in the capacity to handle the language, especially by women. The question therefore arises whether what appears to be a growth of affect may in fact be no more than a growth in the capacity to express emotions on paper, stimulated by growing familiarity with writing and influenced by the reading of novels. (Stone 1977: 13)

Affect, or feeling, then is not simply given but is entangled with the conventionalising and increasingly complex linguistic representations of 
introspection. On a textual level, feeling is generated when we "see through someone else's eyes". ${ }^{50}$ The term focalization, according to Gérard Genette (1983 [1972]) and Shlomith Rimmon-Kenan (2009), refers to this point of view of a text but also includes cognitive, emotive, and ideological orientations rather than just being an answer to the question "who sees?" in a narrative. The identification with Others thus is central to the novel form but, I would argue, cannot simply be understood as generating progressive empathy as discussed in relation to the governmental aspects of sympathy. The representation of subjectivity in writing and modes of identification are part of processes of inclusion and exclusion. We could say that early Black autobiographical accounts narratologically perform avant la lettre what W.E.B. Du Bois later called "double-consciousness" ${ }^{11}$ in his "Of Our Spiritual Strivings" in The Souls of Black Folk (2008 [1903]: 8). The narratives present Black introspection to a predominantly white audience and in this process perform a reflection of what it means to be seen through the eyes of another; in this way, the texts also alter conceptions of modern subjectivity. Thus, if we understand modern subjectivity and slavery as intertwined phenomena, historically, philosophically, and aesthetically, and I believe we should, then we need to reconsider Ian Watt's account of the rise of the novel from a transatlantic perspective.

\section{The Rise of the Novel Reconsidered (Again)}

According to Watt's sociological so-called triple-rise theory, England, as a result of the rise of modern industrial capitalism and the spread of Protestantism, develops a powerful, more and more literate middle-class literary market that gives birth to formal realism with the novel becoming the most popular narrative form departing from the older romance. No longer allegorical, but based on psychological insight of characters, the novel-usually published in serialised instalments and disseminated via circulating libraries-purportedly is the genre of the modern individual. Accordingly, Watt positions Daniel Defoe's Robinson Crusoe (2003 [1719]) prominently as the "first novel" (2000 [1957]: 74). ${ }^{52}$ However, he also acknowledges the great demand for shorter printed materials such as newspapers and pamphlets. By now, Watt's more than fifty-year-old account of how the novel "rose" to fame has attracted critiques, more nuanced revisions, and amendments as, compiled for instance, in the 
instructive double edition of Eighteenth-Century Fiction "Reconsidering the Rise of the Novel" edited by David Blewett (2000).

In addition to the often-voiced male bias in Watt's account which failed to seriously consider female writers in general (cf. Armstrong 1987) and Aphra Behn's prose in particular (cf. Todd 2000), John Richetti criticises Watt's "teleological bias" (1969: 2) in his "grand narrative". ${ }^{53}$ Similarly, Michael McKeon contests the postulated homogeneity of earlier writing of the Reformation which arguably already shared many qualities of the novel, Watt's over-emphasis on the impact of the urban middle class, which does not account for the ongoing authority of the aristocracy (especially in rural England), as well as the failure to adequately acknowledge the very different tones of eighteenth-century writing ranging from Defoe's empiricism to Sterne's parody (1985: 169-170).$^{54}$ Furthermore, in contrast to Watt, scholars like Richetti (2012) and David Duff (2012) turn to the Continental tradition of novel criticism and highlight Georg Lukács's and Mikhail Bakhtin's contributions to the field, who both position the traditional epic as counterpart to the modern novel (rather than the romance as Watt does). In this understanding, Don Quixote by Miguel de Cervantes (2003 [1605 and 1615]) is often considered the earliest European novel. Accordingly, departing further from a linear conception of how genres develop, Duff (2012), for instance, revisits Bakhtin's concept of "novelization" (Bakhtin 1994: 6-7), which favours an intertextual aesthetic perspective and became influential for a more poststructuralist understanding of literature. Here the "newness" of the novel is seen as a self-reflexive distance from the epic. This line of critique has become a productive counter frame to what Lennard Davis calls Watt's "applied knowledges"- "using philosophy, sociology, and formalism" to analyse the novel (Davis 2000: 490).

Hence, while I generally lean strongly towards a "Continental" poststructuralist understanding of literature (and I will come back to Bakhtin's model of dialogicity and the concomitant polyphony of the novel (1994: 45-49) in my readings), one thing that remains convincing in Watt's "applied" Anglo-American account to this day is the link between conceptions of the modern individual and writing (cf. McKeon 2000: 270). As McKeon states, "the novel is the quintessentially modern genre, deeply intertwined with the historicity of the modern period, of modernity itself" (2000: 254). While The Rise of the Novel certainly suffers from the mentioned "over-emphasis on the discontinuity with which the transition to modernity was achieved" (McKeon 2000: 274), the idea of "authentic" 
modern forms of feeling is a relevant marker of the "novelty" of eighteenthcentury writing and formative of enlightenment subjectivity as an agglomeration of modernity — granted that Watt's timeline can easily be challenged as starting either too late, as McKeon and Richetti have it, or, too early, as Downie suggests and which thus ties in with postcolonial demands of less teleological progress narratives that should be extended to descriptions of aesthetic generic development. Watt defines as the generic characteristic of the novel the "truth to individual experience-individual experience which is always unique and therefore new" (2000 [1957]: 13). Nonetheless, eighteenth-century scholars like Hunter (2000: 234) also point out that the reading public for this "new" kind of introspective writing is actually more diverse than Watt's term of the "middle class" suggests, which is really only a nineteenth-century formation. The emerging public sphere included readers from the higher and lower ranks of society. ${ }^{55}$

There is powerful history here of the expansion of reading as a phenomenon, of its diversified uses and possibilities, of why writers began to expand and define their horizons of possibility as they came to be aware of audiences and marketing sources previously unknown or non-existent. Watt does not get everything right about the particulars of expanded literacy, including its timing and class strata, but his sense of a deeply changed economy of information exchange has made a lot of subsequent work possible, including almost everything now gathered under the aegis of the history of the book and most good historical genre theory. (Hunter 2000: 231-232)

In this understanding, the emerging European middle class (or reading public in less class-specific terms) shapes a new form of public discourse, which philosopher Jürgen Habermas has famously described as a civic public (cf. 1991: 27). ${ }^{56}$ This public sphere is closely linked to conceptions of the family unit: "The privatized individuals stepped out of the intimacy of their living rooms into the public sphere of the salon, but the one was strictly complementary to the other" (Habermas 1991: 45). For my purpose then another value of Watt's account rather than a purely poststructuralist focus on intertextuality is to look at the material conditions that gave rise to this modern public — a public, which, I argue, needs to be framed as transatlantic from the moment of its emergence.

Consequently, one needs to take into consideration the presence of early Black literary voices, such as Equiano and Sancho, during the rise of European modernity in the eighteenth century. While both Watt (cf. 2000 
[1957]: 51-52) and Habermas (cf. 1991: 18) acknowledge that the colonies are crucial for the development of the public sphere-Watt states that the new print culture reached almost the entire English-speaking world including Ireland and the plantations - they fail to frame this as a reciprocal relationship and focus almost exclusively on the metropole (which in some ways is telling the story of coffee house culture without the plantations where consumer goods such as sugar, cacao, and coffee were produced first by the enslaved and later by indentured labourers) (cf. Mintz 1986; Sandiford 2000; Sussman 2000: 110-129).

What seems indisputable then is that while the rise of the novel no longer holds true as an uncontested linear account of how the modern bourgeois novel came into being, it still offers many points of departure that can raise awareness of how modernity began to be told as a specific (global) story, as an account that modern men and women could aspire to. The preeminent role of literature in the growing (transatlantic) public sphere should therefore not be underestimated. It is no coincidence that in one of the most influential articles in the mentioned strand of historical research which emphasises global entanglements, "Provincializing Europe: Postcoloniality and the Critique of History" (1992), Dipesh Chakrabarty often references literature and specifically autobiography as a prominent arena in which conceptions of modernity were established and challenged.

Catherine Gallagher compellingly remarks that it is not necessarily factuality that is seen as a criterion to judge "realist" novels by but their believability and plausibility, which in fact privileges emotional investment in fictional characters rather than real stories (cf. 2006: 346). Therefore my reading of testimonies, letters, travel writings, and novels next to each other also underscores that "the novel" is not the sole "literary" genre that helped bring about this change. ${ }^{57}$ The concern regarding the degree of factuality versus fictionality in differentiating these sources is, of course, valid-with "fictionality" often depicted as a crucial indicator of the danger of "popular", non-religious writing and reading, which was considered a threat, specifically to the supposedly impressionable minds of "women, children, and servants" (Armstrong 1987: 18; cf. also Sussman 2000: 11; Warner 2000). Nonetheless, as I will maintain, it still seems pertinent to position Defoe's Robinson Crusoe - framed by an increasingly conventionalised fictional editor as a supposedly factual first-person account after all ${ }^{58}$ —next to Equiano's allegedly "factual" Interesting Narrative (2003 [1789]), whose "truth claim" today is contested more than ever (cf. Carretta 2005a, b). What connects the foundational 
"realism" of both Defoe and Equiano is the assumed truth of introspection and this is also the reason that I will not begin with Aphra Behn's Oroonoko (2003 [1688]) which is indebted still to the courtly romance. ${ }^{59}$ In contrast to Oroonoko's gruesome but noble fate, readers are encouraged to understand the experience and inner lives of Crusoe and Equiano as true or at least believable as they seem like "us", which is underscored by the importance of proper names in these narratives, for example. In my context then it is specifically the familiarity that the accounts of the Black subjects produce which prompts me to read them with their novelistic counterparts. Once more, Gallagher explains how this impacted the emergence of models of affective familial belonging - a sphere that becomes desirable for modern men and women and also marks the entryway for Black Atlantic authors in claiming the status as modern feeling subjects while the legal framework still dehumanises them as chattel.

Novels promoted a disposition of ironic credulity enabled by optimistic incredulity; one is dissuaded from believing the literal truth of a representation so that one can instead admire its likelihood and extend enough credit to buy into the game. Such flexible mental states were the sine qua non of modern subjectivity. Everyone seemed to benefit from them. For example, they may have eased the way into the modern affective family. Since marriageable young people were given somewhat greater freedom of choice starting in the eighteenth century, and were also expected to have a genuine emotional attachment to their spouses, some form of affective speculation became necessary. (Gallagher 2006: 346)

In short, the claim to individual feeling, resulting from what Gallagher calls "affective speculation", is the proposed link between Black testimonies and the rise of those narratives that we call the English novel-a label often applied retrospectively to eighteenth-century fiction and only stabilised in the course of the nineteenth. The emphasis on feeling not only marks the shifts in how marriageable (young) people related to each other, it is also a narrative strategy employed by Black authors to claim subject status in the first place. ${ }^{60}$

Hence, while I am aware of the differences between the kinds of narrative texts contrasted in this book, ranging from novels, autobiographies, letters to travel writings, Black testimony is not to be confused simply with the factual counterpart to the fictional novel. Moreover, my argument is not based on celebratory inclusion or a counter history of radical Blackness. 
Entanglement as I mentioned earlier also pertains to questions of cooption, collusion, and the limits of agency. Here, too, generic and political demands shape the (literary) discourse of these texts. There was a "pressing political necessity of portraying an authentic autobiographical self immediately recognisable within the generic types of black manhood and womanhood serviceable to the abolitionist cause", as Celeste-Marie Bernier (2007: 60) argues. Bernier continues,

The works of these early writer-orators reveals the beginnings of a tradition of protest, which maintained an independent black subjectivity by seeming to satiate the subject-matter demands of abolitionist discourse at the same time as engaging in literary dramatisation and aesthetic experimentation. (2007: 62)

This demonstrates that Black authors very consciously had to write in specific ways to be heard by a majority white audience but this is not simply to say that they could not and did not challenge aesthetic conventions in terms of form and content. ${ }^{61}$

Thus, in extension of Watt's rise of the novel argument and the concomitant critique of his account, I want to show that the development of the novel form can be positioned in relation to entangled tonalities that not only gave rise to more "realist" expressions of gendered introspection, as is often argued, it can and should also be linked to the contestation of the dehumanisation of people of African descent by claiming (British) familiarity. For such an endeavour a transdisciplinary dialogue between the introduced historical research on European modernity and the history of transatlantic slavery with the study of literary texts (and their specific aesthetic strategies) seems pertinent. ${ }^{62}$ This book thus profits from and partakes in a growing field of eighteenth-century and Victorian literary studies that conceptualise the rise of the novel as a global literary history, or, in other words, it is invested in the concerted efforts to "provincialise" European literary canons.

Interestingly, this debate is currently associated with a range of labels such as atlantic or transatlantic (literary) studies-approaches that seem less inclined to use the word "postcolonial" that was ubiquitous in 1990s literary criticism, which might have to do with the strong (but somewhat short-sighted) association of the term postcolonial simply with a temporal "after" colonialism. ${ }^{63}$ These interdisciplinary trans/atlantic approaches also productively challenge demarcations of literary periodisation (with 
more and more studies dealing with much greater or unconventional time frames, such as Baucom (2005) or Laura Doyle's Freedom's Empire: Race and the Rise of the Novel in Atlantic Modernity (2008), in order to do justice to the longue durée of European modernity). ${ }^{64}$ In the following chapters, I want to explore the potential of developing a transatlantic reassessment of the rise of the novel that, similar to the historical concepts of entangled histories, focuses on how we can reread the emergence of specific aesthetic registers in novel writing as entangled transatlantic tonalities. Hence, my attempt is to combine a materialist history of the rise of the novel that has profited from Watt's theory with a poststructuralist and postcolonial epistemology that is interested in how narrative forms are intertwined with networks of power and our imagination of (national) identities. I explicitly understand this endeavour as aligned with the project of postcolonial literary studies rather than an overhasty departure from it. Therefore, as a final step preceding the actual readings, I will revisit Edward Said's writing on counterpoint to explain how a focus on entangled tonalities seems especially suited if one wants to provide a transatlantic perspective on the rise of the British novel.

\section{ENTANGLED Tonalities}

In the wake of Foucault's poststructuralist critique, the rise of the novel also needs to be situated within a larger web of knowledge and power. As Davis argues, the novel is now seen "as a regulatory political discourse that served to construct the modern subject" (2000: 494) which diverges from Watt's "applied" understanding of the novel. This line of critique is closely associated with what became known as postcolonial literary studies which tends to depart from an assessment of nineteenth-century imperialism. In the wake of Said's (1994) foundational work on imperial culture, postcolonial literary studies for a long time has therefore focused either exclusively on how writers in Britain, such as Jane Austen, Charlotte Brontë, or William Makepeace Thackeray, have been shaped by the culture of imperialism (cf. Azim 1993; Perera 1991; and Brantlinger 2009 for a general overview). Or, the critical attention was shifted to the literatures in English across the globe with an emphasis on the localised meanings of "oppositional writing" that is seen as "writing back" to the canon only in later twentieth-century postcolonial literature. This field is largely inspired by the path-breaking study The Empire Writes Back by Ashcroft et al. (2002) (cf. also Eckstein 2007 for an overview). ${ }^{65}$ Thus, despite the double focus 
of postcolonial theory as a temporal after colonialism and an epistemological beyond colonialism, postcolonial literary studies have privileged this model of writing back to the centre, a rejection of Eurocentrism only after the fact of European modernity and imperialism. ${ }^{66}$

This yields two problems. First, this temporal frame excludes or at least impairs analysis of sources predating the high imperialism of the nineteenth century and, secondly, this view stabilises the notion of a hegemonic metropolitan centre which is only ever questioned retrospectively. The focus on entanglement is meant here as a challenging of both the temporal dimension and the ways in which canonical and marginalised authors are juxtaposed. Accordingly, reading marginalised and canonical literary voices in conjunction with and against each other becomes increasingly relevant in a contemporary effort to understand modern literary history in a global framework.

One important intervention into the conventional temporal framing of postcolonial literary studies is Aravamudan's work on French and British writings preceding Said's temporal focus on the nineteenth century in Orientalism (2003 [1978]). In his book, Aravamudan analyses a set of texts that bring about what he calls "Enlightenment Orientalism". He argues that "the oriental tale was an alternative genre to the domestic novel" (2012: 6) which has received too little critical attention by scholars of the novel/novelization. ${ }^{67}$ However, rather than focus on a "transcultural utopian potential" (2012:7) of non-realist writings dealing with the "Orient", as Aravamudan does in his pertinent comparatist critique of national(ist) literary history, my emphasis is on entanglements and the ways in which an eighteenth-century transatlantic enchantment with sentimentalised accounts of Britishness supports rather than opposes the psychological logic of the domestic novel. While I agree that varied accounts of eighteenth-century fiction which include non-realist travel tales are, of course, needed, there is also much to be gained from focusing on how the familiar and the strange concomitantly construct the myth of the bourgeois family. So, somewhat in contrast to Aravamudan, who criticises the "national particularism" (2012: 75) of the rise of the novel narrative, the realist novel can and should, I argue, be understood also as a product of transnational encounter. Differing from Aravamudan's textual corpus, the sources analysed here are not an alternative archive of eighteenth-century prose fiction-quite the contrary, they might be called the "usual suspects". However, this attention to the entanglement of English canonical texts with Black Atlantic autobiographical writings can intervene into 
more established postcolonial temporal frameworks looking at the links between the discourses on the abolition of slavery in the eighteenth century and the rise of a global imperial English culture in the nineteenth century. Entanglement, the contemporaneity of more diverse voices, also challenges aesthetic notions of how English writing developed and hence it is not only Watt's theory of the rise of the novel that needs to come under scrutiny but also Said's postcolonial strategy of contrapuntal reading which he proposed in Culture and Imperialism.

As mentioned before, Said urges scholars to look at the "comparative literature of imperialism" to understand "different experiences contrapuntally" as "intertwined and overlapping histories" (1994: 18). Said explains that contrapuntal reading emphasises the influence of the colonies on metropolitan lifestyles (the references to Australia in Dickens's Great Expectations (2003b [1861]) or to the West Indies and India in Brontë's Jane Eyre (2006 [1847]), for instance) but this acknowledgement of interdependency will also always entail an element of possible resistance (Said 1994: 66-67). Daniel Carey explains Said's contrapuntal reading practice as follows: "As we might expect from his naming of the practice, the first analysis comes from an analogy with music. Said remarks that in classical music, the theory of counterpoint depends on the relationship between multiple themes, none of which are dominant" (2009: 109). In order to produce meaning, imperial culture has brought forward, "a structure of reference and attitude, a web of affiliations, connections [...], which can be read as leaving a set of ghostly notations" (Said 1994: 125) in a text. So, evoking the muted sound of the ghost note of imperialism and colonialism here, much like the figure of the "spectre" that is often evoked in the traumatic history of slavery, the writing of imperialism, in Said's understanding, also entails its own "counterpoint". Nevertheless, Said, seems to frame this form of contrapuntal reading strategy as a retrospective act and, as Gesa Mackenthun cautions, places too strong an emphasis on harmony as an outcome of counterpoint that has "conservative" / New Criticist tendencies (2004: 343). Moreover, Carey criticises that in postcolonial contrapuntal readings of canonical classics, there is a tendency to superimpose anachronistic contemporary categories onto literary texts, a critique that shapes much of literary studies' concerns about cultural studies' methodologies in general and postcolonial readings in particular. In this way, Carey argues, contrapuntal reading quickly turns into what he calls "palimpsestic reading" (2009: 109), overwriting the original text with another. 
In his rereading of Robinson Crusoe against the backdrop of this critique, Carey for instance highlights that the category of "chattel slavery" obscures the more complicated eighteenth-century framework of servitude (cf. also Boulukos 2008: 76-77) which I will discuss in more detail in the chapter on Defoe and Equiano. In addition to Carey's call for postcolonial readings closer to the actual source and the need to take seriously the historically specific connotations of concepts, I want to emphasise another problematic aspect in such postcolonial literary reading practices. Too often these have not taken into consideration the contemporaneous interrelation between "metropole and colony" in focusing on the metropolitan texts exclusively. ${ }^{68}$

Conversely, close readings of early Black British literature tend to overemphasise the colonial subject "mimicking" colonial culture and thus fail to note the investment in Otherness that is necessary for hegemonic selfdefinition. Britain has much to gain in moral standing in highlighting the early modern Black British voices. ${ }^{69}$ What is more, we need to link this problem of "original" and "copy" to the tendency to describe all Black writing as imitative, as Gates has argued in relation to David Hume's (1987 [1742]) dismissal of the Jamaican poet Francis Williams whose accomplishments Hume linked to the mindless repetition of a parrot (cf. Gates 1988: 113). Against this backdrop, elaborating on his concept of "Signifyin(g)", Gates forcefully argues that the trickster game of repetition is much more than a banal copying. Black discourse rewrites the received textual tradition (cf. 1988: 124). I would add that the very fact that the Western tradition is mimicked (and thereby altered) is part of its own understanding of superiority: the success story of the Anglophone novel attests to this form of entanglement. The hegemony of cultural forms is also reliant on their (global) export and inclusion of marginalised perspectives and will in this process of entanglement of course be modified. Concurrently, Brycchan Carey stresses the centrality of slavery in any understanding of canon formation: "We can no longer approach writing about slavery as somehow separate, or as a special case. Rather, we must see it as central to the development of European, American, and African culture, from the fifteenth to the twenty-first centuries" (2005: 13).

Said's contrapuntal reading might be called a well-trodden territory in postcolonial studies, but if applied not only retrospectively, contrapuntal reading, or rather a focus on entanglement as I want to propose, alters histories of modernity, and this path, I argue, has not been explored in all its consequences with reference to the emergence of the modern British 
canon. In English literary studies, we are now faced with the rich plurality of English literatures across the globe and at the same time witness a return to more canonical sources regarding English Literature (writ large) in Britain when it comes to decision making about which texts should be taught in schools and universities and the demands to decolonise syllabi, for example. I want to emphasise the need to apply this globalised lens to English literature in Britain as well. Hence, despite a "global" agenda, my line of enquiry employs a more modest transatlantic perspective, a postcolonial entangled reading predating the high time of imperialism to "zoom in" on the construction of familial feeling with regard to national belonging and canon formations in Britain. ${ }^{70}$ This approach avoids referring to Black British writers in the eighteenth and nineteenth century as a mere curious fact, but acknowledges their presence as indeed formative for the construction of Britishness which we now imagine having become a contested identity only under the auspices of twentieth-century migration. In this understanding modernity is also a product of affective relationality.

In summary, entanglement here is meant to draw on and expand the postcolonial insight that metropolitan and colonial cultures are interlinked and that this exchange shapes cultural artefacts. Entanglement extends the scope of historical enquiry: It can help put into perspective the eighteenthcentury Atlantic challenges to the European enlightenment, addressed in the first part of this book, and the nineteenth-century restructuring of the domestic sphere with respect to imperial expansion, which comes under closer scrutiny in the second part of Familial Feeling. Nonetheless, reading autobiographical writings of the early Black Atlantic in a dialogical or entangled relation with the more canonical literary works is not to suggest that this necessarily amounts to direct intertextual quotes-and in the case of Defoe and Equiano there is also considerable historical distance between the texts. I am more interested in what I perceive as a similarity in tone, a form of writing that produces affective resources of belonging that are equally mobilised from the centre and the margin (which is not to deny different access to cultural capital and power asymmetries among the authors). In this way, I hope to provide a re-evaluation of the development of aesthetic forms of literary self-fashioning - the rise of affective individualism that I understand as sutured to what I have called "familial feeling".

For this purpose, I draw, as mentioned, on the immensely helpful discussion of aesthetic tone which Ngai has introduced in her elaborations on "ugly feelings" (2007). Focusing on US-American Modernist writing, 
Ngai offers valuable tools for the study of feelings in literature, always a textual representation of affect after all, which seems especially delicate if the focus is on non-contemporary sources adding further distance to the supposed extra-textual affective dimension. Ngai's concept of tone helps bring affective and aesthetic dimensions in conjunction and by deliberately evoking musicality is also reminiscent of Said's counterpoint. It shares characteristics with narratological categories such as "mood"71 and "voice" but should avoid what the New Critics derided as "affective fallacy". Ngai defines "tone" as follows: "[T] he affective-aesthetic idea of tone [...] is reducible neither to the emotional response a text solicits from its reader nor to representations of feelings within the world of its story" (2007: $41)$. It is a "hyper-relational concept of feeling that encompasses attitude: a literary text's affective bearing, orientation, or 'set toward' its audience and world" (Ngai 2007: 43). Tone thus is also not tied to a generic logic; it does not operate on the level of comedy and tragedy as modes ${ }^{72}$ but rather links back to Williams's structure of feeling. It is both aesthetic and political without necessarily being reducible to an identarian logic of representation which would tie specific modes of expression to social positionalities. The entangled tonalities of familial feeling are, again in Williams's terms, “at once interlocking and in tension" (1985 [1977]: 132). They describe how British nationality is considered in relation to inclusion and exclusion specifically before and after the abolition of slavery via representations of familial feeling. Hence, when pairing texts in this study under headings of tonality (which creates a set of tones and is therefore a superordinate category of tone), I am not so much claiming that they share one common aesthetic strategy, but that they can be linked via their specific "affective bearing" or "orientation" regarding Britishness and the family. Some of the juxtaposed texts are characterised by similar discursive and aesthetic means, as the dash in Sterne and Sancho, for example; others employ disparate strategies, as the internal conflicted free indirect discourse in Austen as opposed to the more outwardly directed anger in Wedderburn's pamphlet. Nevertheless, they share, I argue, a likeness of spectrum - as in a similar colour palate that can be used by employing very different painting techniques ${ }^{73}$ - rather than accordance or harmony when it comes to how they relate discourses of familial belonging and Britishness. In my reading of Austen, I will come back to these nuances, for instance, in criticising the underlying claim of harmony in Said's theory of counterpoint which entangled tonalities should explicitly avoid. 
Entanglement thus exceeds the dimension of Verflechtungsgeschichte as shared histories of modernity, it also functions aesthetically as a history of shared tonalities of literature as a world-making process. The Greek term aisthesis describes the capacity to feel. Western theories of aesthetics have taken this as their starting point to develop the sciences of the fine arts, of accomplished expression in literary discourse that would correspond to this idea of refined feeling. Those, however, who have been excluded from these canon-making mechanisms of Western modernity have needed to claim the capacity to feel much more fundamentally. Looking at the archive of abolitionist writing, one is quickly overwhelmed by the mentioned tropes of sentimentality so abundant in the texts of both white abolitionists and early Black writers who emphasise sameness with regard to the capacity to feel. Accordingly, these linguistic representations of suffering could be read as promoting almost the exact tonal opposite of how Ngai characterises Herman Melville's “atonal tone" (2007: 88). In contrast to Melville's form of Modernist detachment, which lacks any obvious offer of empathic identification for the readers, abolitionist writing displays empathic surfeit or "overkill": the beating of human beings, the cutting of family ties, and sexualised violence give an empathising audience all the affective spectacle, often in embellished language, thereby promoting a virtuous Christian impetus of caring righteously. ${ }^{74}$ As a consequence of this oversaturation with sentimentalised suffering, one could argue that readers have actually quickly become somewhat emotionally indifferent to the tonality of this form of writing.

As literary scholars dealing with a topic such as slavery, of which we have so few first-hand documentations, we have to come to terms with the "the slipperiness and elusiveness of slavery's archive" (Hartman 2008: 17). Archives are formations of power and what can be found in them might often be precisely those texts and objects documenting or being instrumental in the oppression of subjects racialised, sexualised, and gendered as the Other. Such a composition of archives can induce feelings of historical disconnection and depression for precisely these subjects and their descendants. Consequently, writing in the wake of the so-called negative turn in queer theory ${ }^{75}$ has drawn attention to the implications of hegemonic temporalities and historiographies foregrounding the negative or "bad feelings" that archival work can entail, especially when enquiring into forms of oppression and of being silenced. ${ }^{76}$

While the questioning of grand narratives and "writing back" are readily seen as modes of resistance, what can the historical archive still tell us 
that might be relevant for thinking the politics of belonging today? I will return to these ethical challenges in any contemporary effort to engage the archive of slavery in the conclusion. The idea of entangled tonalities then is also indebted to queer epistemologies and is meant as a "messy" or "strange" way of engaging with literary history. It is concerned less with separating marginalised and canonical literary voices or clear-cut periodic and genre demarcations than with how the increasingly racialised logic of the British family is narrated in Victorian fiction and how this, in turn, can be linked to the earlier sentimental rhetoric of abolition. For this purpose, it makes sense, in my opinion, to juxtapose autobiographical and fictional longer and shorter prose narratives since Black writing initially was to be found mainly in the realm of the testimonial/autobiographical rather than straightforwardly fictional publications. Becoming a writing subject first of all implies the privilege of literacy as well as the time and means to publish that only a very small minority of Black subjects had access to. Nonetheless, the archive of slavery and its abolition affects definitions of self and Other, it is not a side phenomenon of "official history". In a 2015 essay Gikandi states that the challenge we have to face is to "read the lives of the slaves in the archive of the masters, not to recover the authentic voices of the enslaved, but to witness new voices and selves emerging in what appears to be the site of discursive interdiction" (2015: 92). The construction of a British exceptional moral standing as pioneers of abolition (in contrast to the former colony, the United States) gave subjects like Equiano, Sancho, Wedderburn, and Seacole the opportunity to become modern subjects not after the fact of modernity but as part of emerging modernity. In fact, these Black British voices are constitutive of the very modern foundation of what British enlightenment is capable of. Positioning the Black authors within a framework of resistance versus subversion, as "postcolonial" literary voices in opposition to the canonical authors, seems to obstruct an understanding of their entangled relation to modernity. Writing of the early Black Atlantic stands in a more conflicted relationship to Britishness than being reduced to the periphery of empire whose subjects aspired to be included into the national community of British privilege. A postcolonial interest in the literature of the early Black Atlantic then must resist urges to highlight the extraordinary accomplishments of these authors and rather aim to understand the entanglement of voices from the multiple peripheries and centres as also affecting hegemonic expressions of Britishness. In short, in revisiting the rise of the novel from a postcolonial/transatlantic viewpoint, I am more interested in the disarrayed 
entanglements in and with the past than a presentist affective investment in counter histories. In the following literary readings then, I am not telling a story of "good" versus "bad" appropriations of familial feeling. In this context, Foucault's famous dictum that there is no outside of power, that "there is no binary and all-encompassing opposition between rulers and ruled" (1998: 94), which is at the heart of queer epistemologies, still bears repeating. I am also not concerned with supposedly "authentic" or "natural" familial feelings. Quite the contrary, it is, in fact, the artifice of the different tonalities that I hope to highlight, which again goes hand in hand with an understanding of social norms as reliant on emotionalising and naturalising discourses, as Foucault and Judith Butler maintain.

Hence, the next chapter will focus on eighteenth-century conceptions of race and slavery and how they relate to Britishness which will be discussed in two texts that laid the foundations for claiming "modern familiarity": Daniel Defoe's Robinson Crusoe (2003 [1719]) with its "insular masculinity" and Olaudah Equiano's The Interesting Narrative (2003 [1789]) that promotes an idea of what I call "Oceanic Britishness". Defoe and Equiano both make us "invest" in the foundational idea of individualism despite very different stakes. Their foundational tonality is characterised by the affective establishment of modern subjectivity: familiarity with these literary heroes is achieved via an early version of formal realism based on the representation of introspection as well as retrospection on an "ordinary" life. In the second chapter of the first section, I analyse how the established and already ridiculed style of sentimentalism is evoked by Ignatius Sancho in his letters (1998 [1782]) and by Laurence Sterne in his fictional writing (1998 [1759-1767] and 2005 [1768]) and direct replies to Sancho. Sancho and Sterne in many ways play with disinterest and digressive modes that make their readers notice the discrepancies between a culture of taste and the realities of enslavement. Their digressive tonality is shaped by an overtly sentimental affective bearing towards all topics they address (including slavery) and their lessened interest in representing coherent subjectivity, formally highlighted by digressive excursions, nonlinearity, and the use of the famous dash. The nineteenth-century writing of Robert Wedderburn and Jane Austen shows increasing unease with the ways in which the familial and the colonial sphere are intertwined locating modes of resistance in terms of both content and form. They both promote more active counter strategies in their writings that could be described as resistant: They represent wilful subjects who stand in opposition to the gendered and racialised familial order of the day which is 
achieved via psychological introspection and free indirect discourse in Austen and incendiary rhetoric in Wedderburn. Finally, gesturing towards a new phase of Britain's colonial expansion, we can witness how Charles Dickens as well as Mary Seacole bolster a more nationalist project of Victorian family values in Britain's newfound position of imperial might in the mid-nineteenth century. In their travelogues, they are paradoxically more invested in domesticity and yet imperial in ambition. Their consolidating tonality is characterised by a narrower concept of familial feeling, based on romanticised ideals of motherhood and paternalistic notions of British superiority, combining a liberal critique of slavery in the United States with expansionist imperial logic that is often voiced in overt narrator comment. The chapters of this book thus focus on four different tonalities-foundations, digressions, resistances, and consolidations-and generally follow a chronological order, except for Sancho's writing which is discussed with Sterne despite its preceding Equiano's later Narrative.

The title of this book, Familial Feeling, does not connote one specific register of feeling, such as happiness or sadness. Rather, I am interested in the overall capacity to feel in specific ways, to be recognised as a feeling subject in the first place, which can be seen in the strategy of the Black authors to address their audience as empathising readers. Their expressions of feeling influence who is considered a familiar, or, in Butler's words, an intelligible subject, ${ }^{77}$ belonging to Britain and its increasingly literate (middle-class) public sphere. These developments are consolidated via literary reflections on moral sentiment and sympathy in the eighteenth century and social reform and professionalised philanthropy in the nineteenth century with longer prose forms such as the novel becoming the most relevant genre in this context. It is especially the ambivalence of such an emotionalising register of inclusion and exclusion that I want to trace (as well as the ongoing effects for national memorial cultures, as I argue in the conclusion). The nuclear and the national family become inextricably linked and ever since Samuel Richardson's voluminous epistolary novel Clarissa, or the History of a Young Lady (2004 [1747-1748]), the familial sphere turns into the site of belonging and terror. Looking at texts such as Wedderburn's The Horrors of Slavery (1991 [1824]), Austen's Mansfield Park (2003 [1814]), Seacole's conception of herself as maternal war hero in the Wonderful Adventures in Many Lands (2005 [1857]), or Mrs Jellyby's misguided philanthropy in Dickens's Bleak House (2003a [1852-53]) shows that the way we feel is linked to registers of the familial and the national. These texts set the tone for familial feeling by providing 
foundational ideas of modernity (Defoe and Equiano), playful digressions (Sancho and Sterne), resisting perspectives (Austen and Wedderburn), as well as more conciliatory undertones in relation to empire (Dickens and Seacole).

\section{Notes}

1. Some of the arguments raised here have been published previously in an earlier much shorter version and are reproduced with permission of De Gruyter: Haschemi Yekani, Elahe. 2016. Feeling Modern: Narratives of Slavery as Entangled Literary History. In The Humanities between Global Integration and Cultural Diversity, ed. Hans G. Kippenberg and Birgit Mersmann, 117-134. Berlin: De Gruyter. DOI: 10.1515/9783110452181-009.

2. Blair's speech is quoted in The Guardian: Cf. "Personally I believe the bicentenary offers us a chance not just to say how profoundly shameful the slave trade was-how we condemn its existence utterly and praise those who fought for its abolition, but also to express our deep sorrow that it ever happened, that it ever could have happened and to rejoice at the different and better times we live in today".

https://www.theguardian.com/politics/2006/nov/26/race.immigrationpolicy (accessed 15 April 2018).

3. The museum is in fact a gallery rather than a whole museum located in the Merseyside Maritime Museum.

4. The list and statement can be accessed here: http://www.liverpoolmuseums.org.uk/ism/visit/floor-plan/legacies/blackachieverswall/index.aspx (accessed 15 April 2018).

5. Cf. https://www.theguardian.com/uk-news/2018/apr/15/why-thechildren-of-windrush-demand-an-immigration-amnesty and http://www. bbc.com/news/uk-politics-43792411 (accessed 15 April 2018).

6. I use the word British rather than English because the notion of Britishness is related to both the British Isles and the British empire as encompassing more than one nation. Both terms remain conflictingly related, and it is short-sighted to assume a closed and static national identity of Englishness versus a more flexible and inclusive Britishness. On the one hand, Englishness functions as the powerful norm of imperial identity formation that often superimposes Britishness; on the other hand, both Englishness and Britishness are themselves mobilised in the colonial encounter. Hence, I will often use British in ways that imply hegemonic expressions of Englishness. Catherine Gallagher sees Britishness as a "platform for national heterogeneity" (2000: 80). She explains: "Britain, many would 
now agree, began less as a homeland than as a way of being abroad. It did not pre-exist its empire and then 'expand' overseas, but was instead produced by expansion and might therefore be analysed as a phenomenon of extra-territorialization" (Gallagher 2000: 78). Accordingly, it is important to emphasise that the British empire has never been a conglomerate of homogenous cultures. Evan Gottlieb highlights the importance of the concept of sympathy, as it was developed by Scottish enlightenment thinkers in the eighteenth century, to promote a sense of a shared national identity of the English and the Scottish following the 1707 Act of Union which he calls "sympathetic Britishness" (2007: 18). He not only highlights Defoe's involvement in these endeavours, he also shows the close links between feeling and national identity that I explore from a transatlantic rather than inner-British perspective.

7. Gikandi has aptly characterised the situation of the slave as shaped by "temporal dislocation" and "genealogical isolation" (2011: 86). He stresses reading and writing as ways to reclaim subjectivity, and he mentions Sancho as a prime example.

8. In contrast to Firdous Azim's important study The Colonial Rise of the Novel (1993), which traces the theme of imperialism and its effect on subject-formation in writings by Aphra Behn, Daniel Defoe, and the Brontës, I postulate an affective tendency towards Britishness that works from the centre and the margin simultaneously and can produce more ambivalent effects of inclusion and exclusion than a straightforward disavowal of the Other.

9. Elizabeth Barnes uses the phrase "familial feeling" specifically in relation to US-American sentimentalism: "In American fiction and nonfiction alike, familial feeling proves the foundation for sympathy, and sympathy the foundation of democracy. For American authors, a democratic state is a sympathetic state, and a sympathetic state is one that resembles a family" (1997: 2). While her argument of linking the personal to the political via sympathetic identification with the "national" family is indisputable, she concedes that claiming this feeling as exceptionally "American" is more an assertion of the American authors of the period (cf. 1997: x) than a persuasive form of distinction from British forms of "familial feelings". My readings, which emphasise the entanglement of such national narratives across the transatlantic sphere, will underline this. In his study on contemporary queer liberalism and the continuing racialisation of intimacy called The Feeling of Kinship, David Eng contests "romanticized notions of privacy and family as outside capitalist relations of exploitation and domination" and urges us to "resist the idealized notion of family and kinship relations as somehow removed from or eccentric to the racial tensions" (2010:8). The use of the phrase "familial feeling" then tries to acknowledge the pow- 
erful inclusionary force of discourses of the familial while simultaneously intervening in naturalising and racist assumptions about the very make-up of the national family.

10. However, Stone calls for more precision in distinguishing how capitalist aspirations promoted these smaller family units in the upper middle class before the labouring classes embraced the model (cf. 1977: 664). This spirit of capitalism then is not only linked to working conditions but, much in accordance with my argument, with the public imagination of individualism promoted in the literature of the time. Sarah Maza (1997) too cautions against an over-emphasis of class/bourgeoisie to describe the growing importance of the nuclear family in the eighteenth century and draws attention to sentimentalism and the idea of authentic feeling subjects who enter a contractual relationship-one that promotes gendered inequalities.

11. Pierre Bourdieu, too, emphasises such regulatory mechanisms that are dependent on "obliged affections and affective obligations of family feeling (conjugal love, paternal and maternal love, brotherly and sisterly love, etc.)" (1998: 68). For a discussion of the massive demographic shifts in the nineteenth century, cf. Kertzer and Barbagli (2001).

12. What is more, Albrecht Koschorke has argued that while religious patterns lose cultural authority, they keep their normative function in these processes of secularisation: "The role of the heavenly father in the Holy Family is replaced by the 'state as father' in the modern nuclear family" (2001: 122 , my translation).

13. Anderson's much-cited definition of nations as "imagined political community" reads as follows: "It is imagined because the members of even the smallest nation will never know most of their fellow-members [...]." He continues, "it is imagined as a community, because, regardless of the actual inequality and exploitation that may prevail in each, the nation is always conceived as a deep, horizontal comradeship. Ultimately it is this fraternity that makes it possible, over the past two centuries, for so many millions of people, not so much to kill, as willingly to die for such limited imaginings" (1991: 6-7).

14. Vera Nünning (2003) reads the expansion of traditional "female attributes" to the men of feeling and the increased visibility of female authors as a blurring of gender differences in the eighteenth century. As a result of the conservative turn in the 1790s, the gendered public and private spheres regain prominence. This shift will also become apparent in the renewed interest in motherhood rather than sentimental men in Victorian fiction that I discuss in the second part of this book.

15. The volume Affect and Abolition in the Anglo-Atlantic edited by Stephen Ahern (2013) also provides a good overview of the flourishing field. Moreover, Levecq (2008) offers a comparison of the ways in which senti- 
mental discourse employed by African American and Afro-British authors shaped notions of liberty helping to bring about diverging British and US-American political cultures in the second half of the eighteenth century. There is also scholarship that explicitly links Romanticism and slavery such as Lee (2002) and Thomas (2000).

16. However, Jonathan Rose (2006) shows that despite growing literacy, many Victorians still predominantly read general literature such as history as opposed to only about forty percent novels.

17. Carey, too, notes a diminishing of the sentimental rhetoric: "By 1807 , when the British slave trade was finally abolished, most-but not all-abolitionist rhetoric had moved on from sentimentalism" (2005: 9).

18. In the second half of the eighteenth century initially a religiously motivated conception of polygenesis (the idea that there were entirely different species of human beings rather than one common Godly creation) was employed to increasingly racialise African difference and legitimate slavery as compatible with Christianity, sometimes incorporating the idea of the hierarchical great chain of being. This view was then translated into forms of scientific racism and an essentialising of biological difference at the beginning of the nineteenth century as Boulukos (2008) argues (cf. also Sussman 2000: 193-194). In the second half of the nineteenth century, as a result of the Darwinian revolution, this thinking is debunked and a common root of humanity (monogenesis) becomes the scientific consensus. However, difference is quickly re-established as civilisational progress. Darwinian ideas of biological evolution-which are, in fact, much more open and less theological-teleological—are problematically and simplistically translated into Social Darwinist conceptions, which bolstered a paradoxically humane conception of colonialism as the "civilising mission", as Armstrong has argued: "Were polygenetic thinking to prevail, the British public would have to understand the colonial enterprise as nothing more than ruthless competition for goods and territory in which Europeans were proving to be the superior predator. By coming up with a theory that opens a temporal gulf between primitive and modern man and yet includes all variations of man within a single species, Darwin's theory provided not only a scientific explanation for British superiority. It also offered a way for the British to consider themselves more humane than the people they dominated while profiting by their competitive superiority over colonial populations" (2005: 129). Cf. also Haschemi Yekani (2011: 43-46) for a discussion of how Darwin's theories were employed to promote a new colonial ideal of British manliness at the turn from the nineteenth to the twentieth century.

19. David Armitage introduces a more precise taxonomy and distinguishes Circum-Atlantic history as "the transnational history of the Atlantic world" 
from Trans-Atlantic history, which he describes as "the international history of the Atlantic world" and finally Cis-Atlantic history, that is, "national or regional history within an Atlantic context" (2002: 15). In this understanding, my project falls most closely within the last category because, despite the transatlantic crossings (mainly to the United States and the Caribbean but later to Asia, too), I am interested in how these international networks feedback into a specific British self-understanding that is mobilised by both Black and canonical authors.

20. This framework, of course, also extends into twentieth-century and contemporary efforts to take into consideration increased globalisation and the resulting "multiple modernities" as S.N. Eisenstadt (2000) calls this proliferation of the contemporaneity of Western and non-Western forms of "being modern".

21. More recently, for instance, Carina L. Johnson and Catherine Molineux proposed a "transimperial" focus on material traces to examine the "histories of extra-Europeans in Europe" (2018: 90) and their involvement in European self-definition.

22. As is well-known, Captain Luke Collingwood of the Liverpool ship Zong had thrown 131 weakened enslaved Africans of his "cargo" overboard to subsequently claim compensation for his "loss" from the insurance. The (first) court case, which ruled in favour of the owners of the ship, outraged part of the British public, including Equiano and Granville Sharp, who consequently, unsuccessfully tried to charge the crew with murder (cf. Walvin 2007: 147). The first verdict was later annulled in a second case that eventually revoked the insurance claim (but there never was a murder charge, which would have challenged chattel slavery more fundamentally).

23. David Dabydeen's long narrative poem Turner (2002 [1994]), Fred D'Aguiar's novel Feeding the Ghosts (2014 [1997]), and M. NourbeSe Philip's poetry cycle Zong! (2011 [2008]) are among the most well-known contemporary literary responses to the Zong massacre.

24. Gilroy defines the culture of the Black Atlantic as follows: "the stereophonic, bilingual, or bifocal cultural forms originated by, but no longer the exclusive property of, blacks dispersed within the structures of feeling, producing, communicating, and remembering" (1993: 3).

25. Cf. Michelle Wright (2004: 35-39) for a discussion of the colonialist implications of Hegel's thinking. Furthermore, Wright shows how in repudiating the Othering of Blackness by European theorists of enlightenment, the first generation of twentieth-century African and diasporic counterdiscursive thinkers of Black subjectivity at times replicated heteronormative assumptions that are so ingrained in ideas of national belonging. 
26. Stephen Fryer's Staying Power (2010) remains the most comprehensive historical account of Black people in Britain and is one of the main reference books for the study's historical framework. Kathleen Chater (2009) provides more in-depth demographic insight into why it remains difficult to ascertain reliable numbers about the actual Black population of the time.

27. Cf. Swaminathan (2009) for an analysis of the shifting rhetoric in debating the slave trade in Britain.

28. Generally, there are two diverging opinions among historians which factors let to abolition: those who understand this as a success of humanitarianism versus those who favour a more economic framework. For helpful critical overviews of these debates, cf. Boulukos (2013); Brown (2006: 13-22); Ellis (1996: 50-51); Sussman (2000: 11-14). Additionally, Lisa Lowe emphasises that the attempts to keep the sugar industry profitable coincided with wide-spread fear of "Black revolution in the colonies" (2015: 13) and this will be taken up in my reading of Wedderburn.

29. Sussman speaks of "anxieties" that led to a shift in public opinion from an initial pro-slavery stance following the 1713 Treaty of Utrecht, which had granted Britain the monopoly in the Atlantic slave trade. Specifically, the colonial expansion resulting from the Seven Years' War (1756-1763) and the following loss of the American War of Independence (1775-1783) gave rise to concern that Britain was relying too strongly on the colonies and the Atlantic economy (cf. Sussman 2000: 13; also Woodard 1999: 2).

30. There is now some speculation whether Mansfield's own family history might have been an influence on his decision as Dido Elizabeth Belle (1761?-1804), who was the illegitimate daughter of his nephew Sir John Lindsay and an enslaved woman, was his protégée and lived at his house. The 2013 British feature film Dido Elizabeth Belle (dir. Amma Asante) is based on her life story.

31. Ellis also names other topics such as prostitution, which, like the consumption of alcohol, is an important arena of social reform and regulation of populations which are increasingly framed as a danger to "national hygiene" in the course of the nineteenth century.

32. In her widely cited introduction to Sensibility, Janet Todd writes, "The arousal of pathos through conventional situations, stock familial characters and rhetorical devices is the mark of sentimental literature. Such literature buttonholes the reader and demands an emotional, even physical response" (1986: 3). It caters to indulgence in depictions of distress which can also quickly evoke embarrassment once too conventionalised. For a discussion of the medical and psychological/affective dimensions of sensibility in eighteenth-century culture, cf. Csengei (2012).

33. Rai offers a reading of Pamela, Jane Eyre, and The Man of Feeling in a contrapuntal relation with texts written by ex-slaves (Mary Prince, Quobna 
Ottobah Cugoano, and Olaudah Equiano). While his discussion of sympathy in relation to Foucault's theory of governmentality is highly convincing and I adopt many of his propositions, his literary readings do not pay enough attention to aesthetic and generic specificities of some of his sources. In contrast to his contrapuntal approach, the entangled readings that I propose aim to highlight more strongly an ambivalence and difference in the literary voices (both hegemonic and marginalised) in the gradual changes from the eighteenth to the nineteenth century. The greatest divergence then in his and my account is the shift that I suggest from eighteenth-century conventionalised claims to humanity, which can be found in the early, often heavily edited or even plagiarised abolitionist accounts that rely on a conception of moral sentiment and sympathy, to nineteenth-century conceptions of social reform and philanthropy. These I believe paved the way for a consolidation of racial difference in an increasingly Social Darwinist Victorian context that laid the foundation for British colonial expansion in the second half of the nineteenth century.

34. Ellis emphasises how the stylisation of feeling hindered political change: "The sentimentalist discussion of slavery is particularly eloquent because of the priority and privilege it accords to the feelings and to the heart, rather than the scopic typologies of complexion and race. Sentimentalism wants to believe that all humanity is equally capable of feeling and that this equality of feeling is not determined or prejudiced by appearance or skin colour. Depictions of slavery are also felicitous to the sentimentalist interest in pain and suffering. In this way, sentimentalist writers had a significant role in the formation of the moral conscience of the abolition movement. [...] However, the sentimentalist approach, while advertising the suffering occasioned by slavery, fails or refuses to move beyond the depiction of its theme to a critique of that theme's subject, slavery proper" (1996: 86).

35. Cf. also Ellis (1996: 127) for more elaboration on the distinction between amelioration and abolition in sentimental fiction.

36. Gallagher highlights how the 1807 ruling radically altered the role of the British navy enforcing the abolition of the slave trade on the Atlantic: "In 1789, they [the British] were the most active slave-traders among European nations, holding 57.9 per cent of the Atlantic trade; by 1808 they had declared slave-trading piracy and were committed to its termination in the Atlantic" (2000: 85).

37. Providing an in-depth reading of the rhetoric used in the debates for and against the abolition of slavery in the British public sphere, Srividhya Swaminathan argues that this discourse contributed to "the idea of a collective national, commercial, moral identity". Further, similar to what I try to show with regard to the formation of a specific form of "familial feeling" in literature, she too, highlights that: "The form of national identity that 
emerged from the slave-trade debates of the late eighteenth century directly contributed to British imperialism in the nineteenth and twentieth centuries" (2009: 9).

38. Boulukos speaks of a "transatlantic gap in legal and social practices of race" (2008: 98).

39. Harriet Jacobs, for instance, describes her visit to London in the following terms: "For the first time in my life I was in a place where I was treated according to my deportment, without reference to my complexion" (2000 [1861]: 204). Regarding the often-voiced allegation that in England the abolitionists fail to adequately address the bleak conditions of the working class at home and prioritise Black suffering, Jacobs counters, "I saw men working in the fields for six shillings, and seven shillings, a week, and women for sixpence, and sevenpence, a day, out of which they boarded themselves. Of course they lived in the most primitive manner; it could not be otherwise, where a woman's wages for an entire day were not sufficient to buy a pound of meat [...]. I had heard much about the oppression of the poor in Europe. The people I saw around me were, many of them, among the poorest poor. But when I visited them in their little thatched cottages, I felt that the condition of even the meanest and most ignorant among them was vastly superior to the condition of the most favored slaves in America" (2000 [1861]: 205). The reasoning against equating the oppression of the British poor with that of American slaves is dependent on tropes of familial feeling. The fact that enslaved families had to fear being torn apart at their master's whim pushes them outside the realm of human compassion as Jacobs elaborates. The focus on familial bonds thus becomes the sine qua non for the call for emancipation. Accordingly, Sandiford emphasises that "descriptions of distressed Africans being separated from their kin are a classic of antislavery sentimentalism" (1988: 50).

40. This strategy continues into the twentieth century, when civil rights activist Paul Robeson "promotes Britain uncompromisingly as the home of freedom despite its role as a colonial power, exhibiting a strategic Anglophilia in order to attack American racism" (Rice 2003: 175).

41. The ideal of domesticity is of course not only reflected in literary publications but also in the great demand for utilitarian conduct books. In her study on bourgeois dispositions of feeling and the middle-class habitus, Jana Gohrisch (2005) analyses fictional and non-fictional texts to show how happiness and contentment were constructed as specific middle-class registers of feeling in nineteenth-century Britain. Gohrisch explores the interaction between conduct books and self-help literature with Victorian fiction to conceptualise how happiness is increasingly linked to the domestic sphere: "For the authors of conduct literature, the family is the central site of individual happiness. Here the disposition for feeling compassion is 
generated, which is to affect the entire society via individual actions and, thus, curb egoism. [...] These cognitions are either rooted in religion or a tradition of moral philosophy that is conveyed through intellectual activities, such as reading and conversations about literature and philosophy" (2005: 125, my translation). At the same time, taking into consideration Foucault's theory of governmentality, one should not underestimate the regulatory power of concepts such as "happiness" that are tied so closely to domesticity and middle-classness. Emotions and politics hence are closely related, as cultural critics such as Lauren Berlant have demonstrated compellingly for the United States. The Declaration of Independence, for instance, which guarantees the right to the "pursuit of happiness", underlines such an emotionalised understanding of politics. Berlant has argued that this framework instrumentalises the notion of personal responsibility as a form of "cruel optimism" (2011) and conceptualises success as an individual achievement thereby ignoring structural mechanisms of inequality. It is such a perspective on how emotional and political discourses are intertwined that I wish to propose for the British context here.

42. Joseph Rezek proposes the term "print Atlantic" (2012) to highlight the role of books as objects of exchange that connected various Englishspeaking cultures across the Black Atlantic.

43. Following an emotionological approach, Stedman analyses the uneasy balance between the increasing expression and simultaneous socially demanded control of feelings. While the studies of Gohrisch (2005) and Stedman (2002) offer insights into historical cultures of Victorian feeling, my focus is on how such literary expressions of feeling challenge as well as consolidate modes of inclusion and exclusion (from marginalised and hegemonic perspectives) in relation to Britain's colonial expansion.

44. Nineteenth-century authors like Austen and the Brontës were aware of the generic demands of the novel in a way that their predecessors Defoe and Richardson were not (cf. Armstrong 1987: 38).

45. Cf. Nelson (2007) for an overview on kinship ties in Victorian England.

46. In a Foucauldian understanding, this form of regulation will also give rise to resistance. The "dark side" of family fortunes is addressed most notably in Austen's Mansfield Park and Charlotte Brontë's Jane Eyre (and already somewhat more satirically in William Thackeray's Vanity Fair (2003 [1848])). More and more, the Caribbean non-white descendants of the plantocracy, such as Robert Wedderburn, demand their share in familial privilege, as will be discussed in Chap. 4 .

47. This Victorian debate is exemplified most clearly in Thomas Carlyle's (1849) infamous essay "Occasional Discourse on the Negro Question" and John Stuart Mill's (1850) dissenting reply. 
48. The so-called woman question, for instance, and the fight for female suffrage, passed only in 1918, continue to shape the public debate in Victorian England. Like the shift in the debate on abolition, the more radical claims of the 1790s for universal suffrage were toned down palpably by 1848 with the decline of Chartism and the passing of the Second Reform Act of 1867. George Eliot's Middlemarch, serialised from 1871 to 1872 and published in one volume in 1874, whose plot takes place in "ante-reform times" (2003 [1874]: 27), can be considered the most important literary reflection of the (in part failed) reform movement and the consequences for the self-conception of the British middle class. It is considered by many critics one of the most elaborate realist novels of psychological interiority. In this detailed depiction of the British "middle station" of life, the politics of abolition also play a small role in Mr Brooke's indecisive political ambitions that mark the move away from the more radical demands of the late eighteenth century: "'Quite right, Ladislaw; we shall make a new thing of opinion here,' said Mr. Brooke. 'Only I want to keep myself independent about Reform, you know; I don't want to go too far. I want to take up Wilberforce's and Romilly's line, you know, and work at Negro Emancipation, Criminal Law-that kind of thing'" (Eliot 2003 [1874]: 459).

49. For an overview of the so-called affective turn, cf. Clough and Halley (2007); Gregg and Seigworth (2010); Weber (2008). Traditionally, emotion has been seen as the cultural expression of affect (which describes bodily reactions) while feeling is sometimes used as an umbrella term that includes both aspects, which is how I employ familial feeling. While affect theorists, and specifically media studies scholars such as Brian Massumi, advocate a clear distinction between affect and emotion, others, especially critics indebted to phenomenology like Sara Ahmed, do not. Ahmed proposes the interchangeability of "emotion" and "affect" because both create bodily sensations and become inseparable in the process of generating meaning. "Emotions are not 'after-thoughts', but shape how bodies are moved by the worlds they inhabit. [...] While you can separate an affective response from an emotion that is attributed as such (the bodily sensations [such as shivering] from the feeling of being afraid), this does not mean in practice, or in everyday life, they are separate" (Ahmed 2010: 32). What is more, the assumed "autonomy of affect" that Massumi postulates (2002: 23-45) neglects that, as Clare Hemmings puts it succinctly, "only for certain subjects can affect be thought of as attaching in an open way; others are so over-associated with affect that they themselves are the object of affective transfer" (2005: 561). For a more elaborate critique of Massumi's ideas, cf. Leys (2011). This distinction of affect and emotion was discussed first in a different context in Dietze et al. (2018). For my corpus, too, the 
distinction between feeling and affect seems far less plausible. The generic convention of autobiographical writing of the formerly enslaved-to testify to experiences first-hand-is part, of course, of an appeal to feeling, as explained in relation to the so-called cult of sensibility. But by providing gruesome details about slavery the texts will also evoke a bodily affective response in their readers; they are a combination of the affective reaction in light of the terror of bodily harm of Others and the (often paternalistic) culturalised value that is bestowed on expressions of refined feeling in a compassionate culture.

50. In contrast to Suzanne Keen's (2007) narratological study on empathy and the novel, which employs interdisciplinary methodologies of cognitive narratology and reader response criticism, my methodology is indebted to the queer interrogation of the politics of emotion that critics like Berlant (2004) and Ann Cvetkovich (2007) have introduced. However, like literary scholar Ngai (2007), I do want to emphasise the need to understand the aesthetics of the representation of feelings as specific tonalities of literary texts.

51. The famous passage defining the concept of "double-consciousness" reads as follows: "It is a peculiar sensation, this double-consciousness, this sense of always looking at one's self through the eyes of others, of measuring one's soul by the tape of a world that looks on in amused contempt and pity. One ever feels his two-ness, - an American, a Negro; two souls, two thoughts, two unreconciled strivings; two warring ideals in one dark body, whose dogged strength alone keeps it from being torn asunder" (Du Bois 2008 [1903]: 8).

52. J.A. Downie analyses the number of published fictional prose writings in England and strongly contests Defoe's status in Watt's account. Downie argues that it is only the later writing of Richardson and Fielding which sparked the wide-reaching demand for novels (cf. 2000: 325).

53. Cf. also Davis (2000) and Folkenflik (2000) for a more general overview of the development of theories of the novel.

54. Nonetheless, Watt is not entirely oblivious to these tonal differences. He concedes that while Jane Austen's writing can be considered most successful in depicting authentic introspection of modern men and women (cf. Watt 2000 [1957]: 297), Tristram Shandy remains "ultimately a parody of a novel" (Watt 2000 [1957]: 291).

55. Robert Mayer (2000) provides a convincing Bourdieu-inspired account of how this new "middle-brow taste", favouring shorter stories, functions as a rejection of the aristocratic romance in the eighteenth century. Boulukos, in turn, links this to the development of English studies as an academic discipline and posits that "the 'middle class' nature of the novel is a prod- 
uct of specific political moments within English studies rather than of the novels themselves" (2011: 378).

56. Davis speaks of the "news/novels discourse" that largely worked as an "undifferentiated matrix" (1996: 70) to highlight the close relationship between journalistic publications/news and the rise of the novel as a development specific to eighteenth-century Britain (which he contrasts to the French/European tradition of the novel). Cf. also Gallagher (2006: 340).

57. There are, of course, numerous important publications (too numerous to list them individually here) which highlight the impact of both drama and poetry for the development of the eighteenth-century public sphere (many dealing specifically with slavery and abolition). However, since my focus is on the ways in which longer prose narratives create notions of familial feeling, which, I argue, is specific to the emotive appeal of prose narratives' modes of narrating introspection and empathy via focalization, I will not offer an extensive discussion of either genre. Said, too, emphasises the singular importance of the novel genre for the stabilisation of bourgeois society and imperialism (1994: 71).

58. Cf. Downie's statement: “The strategy of Defoe's prefaces and their insistence on the 'factuality' of the spurious autobiographies they purport to introduce is well known. It was a marketing ploy which seems to have worked. It was not so much that contemporaries could not distinguish between fact and fiction, could not tell novels from news-rather the reverse. The primary conventions were already in place, but Defoe had problematized them" (2000: 321$)$.

59. Despite the elaborate conventionalised truth claim of the "eye-witness" homodiegetic narrator in Oroonoko, which is the reason critics like Davis (1996: 108) argue that the text should be read as part of the novel tradition, the lack of authentic introspection as a defining feature of the novel makes me consider Oroonoko as more closely affiliated with the romance, as does Boulukos. He explains: “Behn's hero lives in a lavish court, like any hero of romance, although the trappings are distinctly oriental; Defoe's Africans by contrast are nameless, naked savages in a bleak, empty landscape". Behn still “orientalises" Africans as courtly heroes while Defoe "others" them as the foil against which he can narrate an increasingly modern version of individualism (Boulukos 2008: 40).

60. Gallagher elaborates that fictionality rather than factuality, in fact, makes it easier to empathise with characters: "we, like our eighteenth-century predecessors, feel things for characters not despite our awareness of their fictionality but because of it" (2006: 351-352). This claim seems well reasoned if we take into consideration the many sentimentalised accounts of Black suffering that were popular precisely because a white reading audience 
could indulge in tearful renunciation of slavery without immediately being challenged into action or critical self-reflection.

61. The choice to focus on authors of the early Black Atlantic who contributed significantly to the four tonalities analysed in this study, means that other narratives including those by Ukawsaw Gronniosaw aka James Albert (1772) and Mary Prince (2004 [1831]), which were both written down by white amanuenses, cannot be discussed in greater detail.

62. Tim Watson (2013: 7), for instance, calls on postcolonial literary scholars to engage more with the still fairly unexplored (literary) archive of slave revolts.

63. Eve Tavor Bannet and Susan Manning, for instance, speak of transatlantic literary studies and highlight the "transatlantic print culture" (2012: 2) that was formative of Anglophone exchanges beginning in the seventeenth century. For American studies, the establishment of the Atlantic studies paradigm meant a shifting focus from the United States solely to engage with a broader Atlantic contact zone including the Caribbean and South America as William Boelhower argues (2008). While many of the texts he considers part of the "New Atlantic Studies Framework" are crucial for my understanding of entanglement as well, in his taxonomy (cf. 2008: 88-89), I endorse a postcolonial perspective on how nations come to matter in creating familiarity.

64. Differing in focus and spatio-temporal framing from the present study (analysing English and US-American texts from 1640 to 1940), Doyle argues that "in Atlantic modernity, freedom is a race myth" (2008: 3). The predominance of the "liberty plot", which she regards as constitutive of the English-language novel in both England and the United States, constructs a distinctly racialised white capacity for freedom. She criticises that Watt's account participates in a "Whig' narrative" of liberation (2008: 20). However, Doyle also emphasises the agency of Black authors in this context, who "do more than ventriloquize the dominant liberty narrative with subversive differance. They implicitly generate an African-Atlantic archeology of it, installing themselves as its absent origin" (2008: 6). While I find many insights in Doyle's study that also discusses how the trope of rape was instrumental for the increasing psychologising introspection of the realist novel convincing, I want to highlight the need to pay more attention to the specific affective and ambivalent framings of familial and national belonging in the individual literary texts. The concentration on the sphere of familial feeling highlights important points of rupture (aside from the diverse aesthetic projects) that the larger scope of Doyle's emphasis on the "liberty plot" threatens to brush over.

65. While Ashcroft, Griffiths, and Tiffin suggest to use the term "postcolonial", "to cover all the culture affected by the imperial process from the 
moment of colonization to the present day" (2002: 2), their very persuasive argumentation that the coinciding of the "development of English as a privileged academic subject" and "the growth of Empire" (2002: 3) in the nineteenth century affected the increasing success of resistant postcolonial or so-called New English Literatures in the formerly colonised territories somewhat obstructs the view on earlier English transatlantic writing preceding independence. So, while nineteenth-century (and contemporary) literature is often analysed in postcolonial literary studies, the connection to the earlier debate on slavery in the eighteenth century has only been addressed more recently.

66. For a more elaborate critique of the temporal and spatial connotations of the term "postcolonial”, cf. McClintock (1995: 10-14).

67. While undoubtedly Aravamudan's study is one of the most relevant critiques of Watt's thesis and an important extension of Said's argument to further eighteenth-century studies, his corollary that this Enlightenment Orientalism amounts to an alternative "cosmopolitanism" (2012: 7) appears somewhat too optimistic. He claims, "Ethnic identities at this time were still fluid, racializing yet not rigidly racist" (2012: 12). I will discuss the need to be careful of uncritical applications of terms such as "race" in relation to texts like Robinson Crusoe (and the work of George Boulukos, Daniel Carey, and Roxann Wheeler is extremely instructive in this regard). Nonetheless, rather than propose a clear separation between nineteenthcentury biological (rigid) racism and earlier forms of (fluid) Othering (as Aravamudan does), the focus on the history of slavery, I argue, promotes an understanding of shifting forms of racialisation that both produce very material consequences. Boulukos, too, emphasises that institutionalised racial oppression precedes nineteenth-century scientific racism and puts forward the thesis that the discourse of amelioration common in the 1760s in legal hearings as well as in sentimental fiction like Sarah Scott's The History of Sir George Ellison (1996 [1766]) (preceding the abolitionist discourse of the 1780s) paradoxically underscore a differential view, "implying that Africans are somehow less human, less endowed with reason and feeling, than Europeans" (2008: 140). This ties in with later biological conceptions of race and the shift from the mentioned concept of monogenesis to nineteenth-century polygenesis (Boulukos 2008: 10-16). More recently, it is specifically medievalists, such as Geraldine Heng (2015) and Beatrice Michaelis (2014), who show that a reworking of race as an analytical (rather than ontological) category can do important epistemological work, even if applied purposely anachronistically.

68. This demand, to look at the entangled or related literary discourses, is, of course, not new and Frederick Cooper and Ann Laura Stoler had already urged scholars to rethink the postcolonial research agenda in 1997 to anal- 
yse "how both colonies and metropoles shared in the dialectics of inclusion and exclusion" (1997: 3).

69. Homi Bhabha's widely applied (and by now also criticised) concepts of hybridity and mimicry (cf. Bhabha 1994, critically, for example, Young 1995; Brah and Coombes 2000) seem not always to do justice to the simultaneity of different cultures and while he notes the menace of mimicry there is a clear directionality implied. Despite the fact that Bhabha himself emphasises that there is no stable original culture, it becomes difficult in his reasoning to envision an outside of colonial discourse or a colonial discourse that can come into being only in entanglement or equiprimordially with other histories and is not antecedent to them.

70. Accordingly, I will have to (and can) say less about these aspects with regard to the Americas-and other regional contexts, such as Canada, the French-speaking and Spanish-speaking world, which undoubtedly also offer rich conflicting accounts of familial belonging in the turn from the eighteenth to the nineteenth century.

71. Tone could also be framed as an "attitude" that the text transpires (and might thus produce a specific mood in its readers, which we can however only speculate about). Genette's understanding of "mood" is based mainly on the "regulation of narrative information" according to distance and perspective (cf. 1983 [1972]: 161-211; 1990 [1983]: 41-43). In what he calls an "ontology of literature" Hans Ulrich Gumbrecht in turn links "tone", "atmosphere", and the German term "Stimmung", which evokes associations with mood, climate, and the human singing voice (2012: $2-5)$. However, in contrast to his explicitly ahistorical and apolitical emphasis on the open connection of prosody and affect (as a counter model to representation), I understand tonality as deeply enmeshed with the realm of political feelings. I do not think that aesthetics necessarily can be reduced to identarian logics of representation, but I am also deeply sceptical of assuming aesthetic immediacy because, as Hemmings earlier quoted critique of Massumi highlights, aesthetics itself is deeply invested in an idea that some bodies are already overdetermined affectively, as is most obvious in the sentimental spectacle of the "suffering slave".

72. In Anatomy of Criticism, Northrop Frye speaks of "tragic" and "comic" fictional modes (1973).

73. I am therefore expanding the notion of tonality used in music and painting as explained in the Oxford English Dictionary: "1. Music. a. The relation, or sum of relations, between the tones or notes of a scale or musical system; $[\ldots]$ a particular scale or system of tones. [...] 2. Painting. The quality of a painting in respect of tone; the general tone or colour-scheme of a picture" ("tonality, n." OED Online. Oxford University Press. Accessed 26 September 2019). 
74. Marcus Wood (2002) discusses the representation of slavery in relation to pornography.

75. For an overview of these debates, cf. Haschemi Yekani et al. (2013).

76. This paragraph draws on a previously published paper written together with Beatrice Michaelis. Cf. Michaelis and Haschemi Yekani (2014).

77. Judith Butler elaborates on the ethical implications of the process of becoming a recognisable subject. In Giving an Account of Oneself, Butler writes, "An account of oneself is always given to another, whether conjured or existing, and this other establishes the scene of address as a more primary ethical relation than a reflexive effort to give an account of oneself. Moreover, the very terms by which we give an account, by which we make ourselves intelligible to ourselves and to others, are not of our making. They are social in character, and they establish social norms, a domain of unfreedom and substitutability within which our 'singular' stories are told" (2005: 21).

\section{Works Cited}

Ahern, Stephen, ed. 2013. Affect and Abolition in the Anglo-Atlantic, 1770-1830. Farnham: Ashgate.

Ahmed, Sara. 2010. Creating Disturbance. Feminism, Happiness and Affective Differences. In Working with Affect in Feminist Readings. Disturbing Differences, ed. Marianne Liljeström and Susanna Paasonen, 31-44. London: Routledge.

Anderson, Benedict. 1991. Imagined Communities. Reflections on the Origin and Spread of Nationalism. Rev. edition. London: Verso.

Aravamudan, Srinivas. 1999. Tropicopolitans. Colonialism and Agency, 1688-1804. Durham: Duke University Press.

- 2012. Enlightenment Orientalism. Resisting the Rise of the Novel. Chicago: University of Chicago Press.

Armitage, David. 2002. Three Concepts of Atlantic History. In The British Atlantic World, 1500-1800, ed. David Armitage and Michael J. Braddick, 11-27. London: Palgrave.

Armstrong, Nancy. 1987. Desire and Domestic Fiction. A Political History of the Novel. New York: Oxford University Press.

- 2005. The Polygenetic Imagination. In How Novels Think. The Limits of British Individualism from 1719-1900, 105-135. New York: Columbia University Press.

Ashcroft, Bill, Gareth Griffiths, and Helen Tiffin. 2002. The Empire Writes Back. Theory and Practice in Post-Colonial Literatures. 2nd edition. London: Routledge. Austen, Jane. 2003 [1814]. Mansfield Park. Ed. Kathryn Sutherland. London: Penguin. 
Azim, Firdous. 1993. The Colonial Rise of the Novel. London: Routledge.

Bakhtin, Mikhail Mikhallovich. 1994. The Dialogic Imagination. Four Essays. Trans. Caryl Emerson and Michael Holquist. Ed. Michael Holquist. 9th edition. Austin: University of Texas Press.

Bannet, Eve Tavor, and Susan Manning, eds. 2012. Transatlantic Literary Studies, 1660-1830. Cambridge: Cambridge University Press.

Barnes, Elizabeth. 1997. States of Sympathy. Seduction and Democracy in the American Novel. New York: Columbia University Press.

Baucom, Ian. 2005. Specters of the Atlantic. Finance Capital, Slavery, and the Philosophy of History. Durham: Duke University Press.

Beckles, Hilary McD. 1997. Capitalism, Slavery, and Caribbean Modernity. Callaloo 20 (4): 777-789.

Behn, Aphra. 2003 [1688]. Oroonoko. Ed. Janet M. Todd. London: Penguin.

Berlant, Lauren, ed. 2004. Compassion. The Culture and Politics of an Emotion. New York: Routledge.

- 2011. Cruel Optimism. Durham: Duke University Press.

Bernier, Celeste-Marie. 2007. 'Iron Arguments': Spectacle, Rhetoric and the Slave Body in New England and British Antislavery Oratory. European Journal of American Culture 26 (1): 57-78.

Bhabha, Homi K., ed. 1990. Nation and Narration. London: Routledge.

- 1994. The Location of Culture. London: Routledge.

Blewett, David. 2000. Reconsidering the Rise of the Novel. Eighteenth-Century Fiction 12 (2-3): 141-146.

Boelhower, William. 2008. The Rise of the New Atlantic Studies Matrix. American Literary History 20 (1-2): 83-101.

Boulukos, George. 2006. The Politics of Silence: Mansfield Park and the Amelioration of Slavery. Novel: A Forum on Fiction 39 (3): 361-383.

- 2008. The Grateful Slave. The Emergence of Race in Eighteenth-Century British and American Culture. Cambridge: Cambridge University Press.

- 2011. The Secret History of the Rise of the Novel: The Novel and the Middle Class in English Studies. The Eighteenth Century 52 (3-4): 361-382.

- 2013. Review Essay: Social Liberty and Social Death: Conceiving of Slavery Beyond the Black Atlantic. In Invoking Slavery in the EighteenthCentury British Imagination, ed. Srividhya Swaminathan and Adam R. Beach, 175-190. Farnham: Ashgate.

Bourdieu, Pierre. 1998. Appendix: The Family Spirit. In Practical Reason. On the Theory of Action, 64-74. Cambridge: Polity Press.

Brah, Avtar, and Annie E. Coombes, eds. 2000. Hybridity and Its Discontents. Politics, Science, Culture. London: Routledge.

Brantlinger, Patrick. 2009. Victorian Literature and Postcolonial Studies. Edinburgh: Edinburgh University Press.

Brontë, Charlotte. 2006 [1847]. Jane Eyre. Ed. Stevie Davies. London: Penguin. 
Brown, Christopher Leslie. 2006. Moral Capital. Chapel Hill: University of North Carolina Press.

Buck-Morss, Susan. 2009. Hegel, Haiti, and Universal History. Pittsburgh: University of Pittsburgh Press.

Butler, Judith. 2005. Giving an Account of Oneself. New York: Fordham University Press.

Buzard, James. 2002. The Grand Tour and After (1660-1840). In The Cambridge Companion to Travel Writing, ed. Peter Hulme and Tim Youngs, 37-52. Cambridge: Cambridge University Press.

Carey, Brycchan. 2005. British Abolitionism and the Rhetoric of Sensibility: Writing, Sentiment, and Slavery, 1760-1807. Basingstoke: Palgrave Macmillan.

Carey, Daniel. 2009. Reading Contrapuntally. Robinson Crusoe, Slavery, and Postcolonial Theory. In The Postcolonial Enlightenment. Eighteenth-Century Colonialism and Postcolonial Theory, ed. Daniel Carey and Lynn Festa, 105-135. Oxford: Oxford University Press.

Carey, Daniel, and Lynn Festa, eds. 2009. The Postcolonial Enlightenment. Eighteenth-Century Colonialism and Postcolonial Theory. Oxford: Oxford University Press.

Carlyle, Thomas. 1849. Occasional Discourse on the Negro Question. Fraser's Magazine for Town and Country (December): 670-679.

Carretta, Vincent. 2005a. Equiano, the African. Biography of a Self-Made Man. Athens: University of Georgia Press.

- 2005b. Questioning the Identity of Olaudah Equiano, or Gustavus Vassa, the African. In The Global Eighteenth Century, ed. Felicity Nussbaum, 226-235. Baltimore: Johns Hopkins University Press.

Cervantes Saavedra, Miguel de. 2003 [1605 and 1615]. The Ingenious Hidalgo Don Quixote de la Mancha. Ed. John Rutherford. London: Penguin.

Chakrabarty, Dipesh. 1992. Provincializing Europe. Postcoloniality and the Critique of History. Cultural Studies 6 (3): 337-357.

Chater, Kathleen. 2009. Untold Histories. Black People in England and Wales during the Period of the British Slave Trade, c. 1660-1807. Manchester: Manchester University Press.

Clough, Patricia Ticineto, and Jean O'Malley Halley, eds. 2007. The Affective Turn. Theorizing the Social. Durham: Duke University Press.

Conrad, Sebastian. 2012. Enlightenment in Global History: A Historiographical Critique. The American Historical Review 117 (4): 999-1027.

Conrad, Sebastian, Shalini Randeria, and Regina Römhild, eds. 2013. Jenseits des Eurozentrismus. Postkoloniale Perspektiven in den Geschichts- und Kulturwissenschaften. 2nd extended edition. Frankfurt am Main: Campus.

Cooper, Frederick, and Ann Laura Stoler, eds. 1997. Tensions of Empire. Colonial Cultures in a Bourgeois World. Berkeley: University of California Press. 
Csengei, Ildiko. 2012. Sympathy, Sensibility and the Literature of Feeling in the Eighteenth Century. New York: Palgrave Macmillan.

Cvetkovich, Ann. 2007. Public Feelings. South Atlantic Quarterly: Special Issue: After Sex? On Writing Since Queer Theory 106 (3): 459-468.

D'Aguiar, Fred. 2014 [1997]. Feeding the Ghosts. London: Granta.

Dabydeen, David. 2002 [1994]. Turner. New and Selected Poems. Leeds: Peepal Tree.

- 2011. The Black Figure in 18th-century Art. http://www.bbc.co.uk/ history/british/abolition/africans_in_art_gallery_02.shtml. Accessed 20 Jan 2016.

Davis, Lennard J. 1996. Factual Fictions. The Origins of the English Novel. New York: Columbia University Press.

- 2000. Reconsidering Origins: How Novel Are Theories of the Novel? Eighteenth-Century Fiction 12 (2-3): 479-499.

Defoe, Daniel. 2003 [1719]. Robinson Crusoe. Ed. John Richetti. London: Penguin.

Dickens, Charles. 2003a [1852-1853]. Bleak House. Ed. Nicola Bradbury. London: Penguin.

—. 2003b [1861]. Great Expectations. Ed. Charlotte Mitchell. London: Penguin.

Dietze, Gabriele, Elahe Haschemi Yekani, and Beatrice Michaelis. 2018. Modes of Being vs. Categories: Queering the Tools of Intersectionality. In Beyond Gender: An Advanced Introduction to Futures of Feminist and Sexuality Studies, ed. Greta Olson, Daniel Hartley, Mirjam Horn-Schott, and Leonie Schmidt, 117-136. London: Routledge.

Downie, J.A. 2000. Mary Davys's 'Probable Feign'd Stories' and Critical Shibboleths about 'The Rise of the Novel'. Eighteenth-Century Fiction 12 (2-3): 309-326.

Doyle, Laura Anne. 2008. Freedom's Empire. Race and the Rise of the Novel in Atlantic Modernity, 1640-1940. Durham: Duke University Press.

Du Bois, W.E.B. 2008 [1903]. The Souls of Black Folk. Ed. Brent Hayes Edwards. Oxford: Oxford University Press.

Duff, David. 2012. Novelization and its Discontents. In Anglistentag 2011: Freiburg. Proceedings, ed. Monika Fludernik and Benjamin Kohlmann, 113-123. Trier: WVT.

Eckstein, Lars, ed. 2007. English Literatures Across the Globe: A Companion. Paderborn: Fink.

Eisenstadt, S.N. 2000. Multiple Modernities. Daedalus 129 (1): 1-29.

Eliot, George. 2003 [1874]. Middlemarch. Ed. Rosemary Ashton. London: Penguin.

Ellis, Markman. 1996. The Politics of Sensibility. Race, Gender and Commerce in the Sentimental Novel. Cambridge: Cambridge University Press. 
Eng, David L. 2010. The Feeling of Kinship. Queer Liberalism and the Racialization of Intimacy. Durham: Duke University Press.

Engels, Friedrich. 2010 [1884]. The Origin of the Family, Private Property and the State. London: Penguin.

Equiano, Olaudah. 2003 [1789]. The Interesting Narrative and Other Writings. Ed. Vincent Carretta. London: Penguin.

Ferguson, Moira. 1992. Subject to Others. British Women Writers and Colonial Slavery, 1670-1834. New York: Routledge.

Festa, Lynn. 2006. Sentimental Figures of Empire in Eighteenth-Century Britain and France. Baltimore: Johns Hopkins University Press.

Folkenflik, Robert. 2000. The New Model Eighteenth-Century Novel. EighteenthCentury Fiction 12 (2-3): 459-478.

Foucault, Michel. 1998 [1976]. The Will to Knowledge. Trans. Robert Hurley. The History of Sexuality, vol. 1. London: Penguin.

- 2008. The Birth of Biopolitics. Lectures at the College de France, 1978-1979. Trans. Graham Burchell. Ed. Michel Senellart. New York: Picador.

Frevert, Ute, et al. 2011. Gefühlswissen. Eine lexikalische Spurensuche in der Moderne. Frankfurt am Main: Campus.

Frye, Northrop. 1973. Anatomy of Criticism. Four Essays. 3rd edition. Princeton: Princeton University Press.

Fryer, Peter. 2010. Staying Power. The History of Black People in Britain. London: Pluto.

Gallagher, Catherine. 2000. Floating Signifiers of Britishness in the Novels of the Anti-Slave-Trade Squadron. In Dickens and the Children of Empire, ed. Wendy S. Jacobson, 78-93. Houndmills: Palgrave.

- 2006. The Rise of Fictionality. In The Novel, ed. Franco Moretti, 336-363. Princeton: Princeton University Press.

Gates, Henry Louis, Jr. 1988. The Signifying Monkey. A Theory of Afro-American Criticism. New York: Oxford University Press.

Genette, Gérard. 1983 [1972]. Narrative Discourse. An Essay in Method. Ithaca: Cornell University Press.

—. 1990 [1983]. Narrative Discourse Revisited. Ithaca: Cornell University Press.

Gerzina, Gretchen. 1995. Black London. Life before Emancipation. New Brunswick: Rutgers University Press.

Gikandi, Simon. 2011. Slavery and the Culture of Taste. Princeton: Princeton University Press.

Gilroy, Paul. 1993. The Black Atlantic. Modernity and Double Consciousness. Cambridge: Harvard University Press.

Gohrisch, Jana. 2005. Bürgerliche Gefühlsdispositionen in der englischen Prosa des 19. Jahrhunderts. Heidelberg: Winter. 
Gottlieb, Evan. 2007. Feeling British Sympathy and National Identity in Scottish and English Writing, 1707-1832. Lewisburg: Bucknell University Press.

Gregg, Melissa, and Gregory J. Seigworth, eds. 2010. The Affect Theory Reader. Durham: Duke University Press.

Gronniosaw, James Albert Ukawsaw. 1772. A Narrative of the Most Remarkable Particulars in the Life of James Albert Ukawsaw Gronniosaw, an African Prince. Ed. Walter Shirley. Bath: Printed by W. Gye.

Gumbrecht, Hans Ulrich. 2012. Atmosphere, Mood, Stimmung: On a Hidden Potential of Literature. Stanford: Stanford University Press.

Habermas, Jürgen. 1991. The Structural Transformation of the Public Sphere. An Inquiry into a Category of Bourgeois Society. Trans. Thomas Burger. Cambridge: MIT Press.

Hartman, Saidiya. 2008. Lose Your Mother. A Journey Along the Atlantic Slave Route. New York: Farrar.

Haschemi Yekani, Elahe. 2011. The Privilege of Crisis. Narratives of Masculinities in Colonial and Postcolonial Literature, Photography and Film. Frankfurt am Main: Campus.

Haschemi Yekani, Elahe, Eveline Kilian, and Beatrice Michaelis. 2013. Introducing Queer Futures. In Queer Futures: Reconsidering Ethics, Activism, and the Political, ed. Elahe Haschemi Yekani, Eveline Kilian, and Beatrice Michaelis, 1-15. Farnham: Ashgate.

Hegel, Georg Wilhelm Friedrich. 1970 [1807]. Phänomenologie des Geistes. Frankfurt am Main: Ullstein.

Hemmings, Clare. 2005. Invoking Affect. Cultural Theory and the Ontological Turn. Cultural Studies 19 (5): 548-567.

Heng, Geraldine. 2015. Reinventing Race, Colonization, and Globalisms Across Deep Time: Lessons from the Longue Durée. PMLA: Publications of the Modern Language Association of America 130 (2): 358-366.

Hobsbawm, Eric J. 1989. The Age of Empire. 1875-1914. New York: Vintage.

Hume, David. 1987 [1742]. Essay XXI: Of National Characters. In Essays. Moral, Political, and Literary, ed. Eugene F. Miller, 197-215. Indianapolis: Liberty Fund.

Hunter, J. Paul. 2000. Serious Reflections on Daniel Defoe (with an Excursus on the Farther Adventures of Ian Watt and Two Notes on the Present State of Literary Studies). Eighteenth-Century Fiction 12 (2-3): 227-237.

Innes, C. Lyn. 2002. A History of Black and Asian Writing in Britain 1700-2000. Cambridge: Cambridge University Press.

Jacobs, Harriet A. 2000 [1861]. Incidents in the Life of a Slave Girl. Ed. Nell Irvin Painter. New York: Penguin.

Johnson, Carina L., and Catherine Molineux. 2018. Putting Europe in Its Place: Material Traces, Interdisciplinarity, and the Recuperation of the Early Modern Extra-European Subject. Radical History Review 2018 (130): 62-99. 
Keen, Suzanne. 2007. Empathy and the Novel. Oxford: Oxford University Press. Kertzer, David I., and Marzio Barbagli. 2001. Introduction. In The History of the European Family. Family Life in the Long Nineteenth Century, ix-xxxviii. New Haven: Yale University Press.

Keymer, Thomas. 2005. Sentimental Fiction: Ethics, Social Critique and Philanthropy. In The Cambridge History of English Literature, 1660-1780, ed. John Richetti, 572-601. Cambridge: Cambridge University Press.

Koschorke, Albrecht. 2001. Die heilige Familie und ihre Folgen: Ein Versuch. 3rd edition. Frankfurt am Main: Fischer.

Lee, Debbie. 2002. Slavery and the Romantic Imagination. Philadelphia: University of Pennsylvania Press.

Levecq, Christine. 2008. Slavery and Sentiment. The Politics of Feeling in Black Atlantic Antislavery Writing, 1770-1850. Durham: University of New Hampshire Press.

Leys, Ruth. 2011. The Turn to Affect: A Critique. Critical Inquiry 37 (3): 434-472. Linebaugh, Peter, and Marcus Rediker. 2000. The Many-Headed Hydra. Sailors, Slaves, Commoners, and the Hidden History of the Revolutionary Atlantic. Boston: Beacon Press.

Lowe, Lisa. 2015. The Intimacies of Four Continents. Durham: Duke University Press.

Mackenthun, Gesa. 2004. The Literary Presence of Atlantic Colonialism as Notation and Counterpoint. Zeitschrift für Anglistik und Amerikanistik 52 (4): 331-349.

Mackenzie, Henry. 2009 [1771]. The Man of Feeling. Ed. Brian Vickers. Oxford: Oxford University Press.

Mallipeddi, Ramesh. 2016. Spectacular Suffering. Witnessing Slavery in the Eighteenth-Century British Atlantic. Charlottesville: University of Virginia Press.

Massumi, Brian. 2002. Parables for the Virtual. Movement, Affect, Sensation. Durham: Duke University Press.

Mayer, Robert. 2000. Did You Say Middle Class? The Question of Taste and the Rise of the Novel. Eighteenth-Century Fiction 12 (2-3): 277-307.

Maza, Sarah. 1997. Only Connect: Family Values in the Age of Sentiment: Introduction. Eighteenth-Century Studies 30 (3): 207-212.

McClintock, Anne. 1995. Imperial Leather. Race, Gender and Sexuality in the Colonial Contest. New York: Routledge.

McKeon, Michael. 1985. Generic Transformation and Social Change: Rethinking the Rise of the Novel. Cultural Critique 1: 159-181.

- 2000. Watt's Rise of the Novel within the Tradition of the Rise of the Novel. Eighteenth-Century Fiction 12 (2-3): 253-276.

Michaelis, Beatrice. 2014. In/Kommensurabilität. Artikulationen von 'Rasse' im mittelalterlichen Nibelungenlied und in Fritz Langs Die Nibelungen. In Durchkreuzte Helden. Das "Nibelungenlied" und Fritz Langs "Die Nibelungen" 
im Licht der Intersektionalitätsforschung, ed. Nataša Bedeković, Andreas Kraß, and Astrid Lembke, 147-163. Bielefeld: transcript.

Michaelis, Beatrice, and Elahe Haschemi Yekani. 2014. Queering Archives of Race and Slavery-Or, on Being Wilfully Untimely and Unhappy. In PostcolonialityDecoloniality—Black Critique: Joints and Fissures, ed. Sabine Broeck and Carsten Junker, 269-283. Frankfurt am Main: Campus.

Mill, John Stuart. 1850. The Negro Question. Fraser's Magazine for Town and Country (January): 25-31.

Mintz, Sidney W. 1986. Sweetness and Power. The Place of Sugar in Modern History. New York: Penguin.

Nelson, Claudia. 2007. Family Ties in Victorian England. Westport: Praeger.

Neumann, Birgit, and Barbara Schmidt-Haberkamp. 2015. Emotionen, Wissen und Aufklärung: Gefühlskulturen im Großbritannien des 18. Jahrhunderts. Das achtzehnte Jahrhundert 39 (2): 139-149.

Ngai, Sianne. 2007. Ugly Feelings. Cambridge: Harvard University Press.

Nünning, Vera. 2003. Maskuline "Amazons of the Pen" und empfindsame "Men of Feeling": Eine thesenhafte Skizze zum Wandel der Geschlechterdifferenz im England des 18. Jahrhunderts. In Das verortete Geschlecht: Literarische Räume sexueller und kultureller Differenz, ed. Petra Leutner and Ulrike Erichsen, 129-154. Tübingen: Attempto.

Nussbaum, Felicity A. 2005. Introduction. In The Global Eighteenth Century, ed. Felicity Nussbaum, 1-20. Baltimore: Johns Hopkins University Press.

Perera, Suvendrini. 1991. Reaches of Empire. The English Novel from Edgeworth to Dickens. New York: Columbia University Press.

Philip, M. NourbeSe. 2011 [2008]. Zong! Middletown: Wesleyan University Press. Prince, Mary. 2004 [1831]. The History of Mary Prince. A West Indian Slave. Ed. Sara Salih. London: Penguin.

Rai, Amit S. 2002. Rule of Sympathy. Sentiment, Race, and Power, 1750-1850. New York: Palgrave.

Reddy, William. 2001. The Navigation of Feeling. Cambridge: Cambridge University Press.

Rezek, Joseph. 2012. The Print Atlantic: Phillis Wheatley, Ignatius Sancho, and the Cultural Significance of the Book. In Early African American Print Culture, ed. Lara Langer Cohen and Jordan Alexander Stein, 19-39. Philadelphia: University of Pennsylvania Press.

Rice, Alan J. 2003. Radical Narratives of the Black Atlantic. London: Continuum. Richardson, Samuel. 2004 [1747-1748]. Clarissa, or The History of a Young Lady. Ed. Angus Ross. London: Penguin.

Richetti, John. 1969. The Rise of the Novel Reconsidered. In Popular Fiction before Richardson. Narrative Patterns, 1700-1739, 1-22. Oxford: Clarendon Press. 
2012. The Novel Before "The Novel". In The Cambridge History of the English Novel, ed. Robert L. Caserio and Clement Hawes, 14-29. Cambridge: Cambridge University Press.

Rimmon-Kenan, Shlomith. 2009. Narrative Fiction. Contemporary Poetics. 2nd edition. London: Routledge.

Rose, Jonathan. 2006. Education, Literacy and the Reader. In A Companion to the Victorian Novel, ed. Patrick Brantlinger and William B. Thesing, 31-47. Malden: Blackwell.

Said, Edward W. 1994. Culture and Imperialism. New York: Vintage.

- 2003 [1978]. Orientalism. New York: Vintage.

Sancho, Ignatius. 1998 [1782]. Letters of the Late Ignatius Sancho, an African. Ed. Vincent Carretta. New York: Penguin.

Sandiford, Keith A. 1988. Measuring the Moment. Strategies of Protest in 18. Century Afro-English Writing. Selinsgrove: Susquehanna University Press.

- 2000. The Cultural Politics of Sugar: Caribbean Slavery and Narratives of Colonialism. Cambridge: Cambridge University Press.

Schwalm, Helga. 2007. Das eigene und das fremde Leben. Biographische Identitätsentwürfe in der englischen Literatur des 18. Jabrhunderts. Würzburg: Königshausen \& Neumann.

Scott, Sarah. 1996 [1766]. The History of Sir George Ellison. Ed. Betty Rizzo. Lexington: University Press of Kentucky.

Seacole, Mary. 2005 [1857]. Wonderful Adventures of Mrs Seacole in Many Lands. Ed. Sara Salih. London: Penguin.

Smith, Adam. 2009 [1759]. The Theory of Moral Sentiments. Ed. Ryan Patrick Hanley. New York: Penguin.

Stedman, Gesa. 2002. Stemming the Torrent: Expression and Control in the Victorian Discourses on Emotion, 1830-1872. Aldershot: Ashgate.

Sterne, Laurence. 1998 [1759-1767]. The Life and Opinions of Tristram Shandy, Gentleman. Ed. Ian Campbell Ross. Oxford: Oxford University Press.

- 2005 [1768]. A Sentimental Journey through France and Italy by Mr. Yorick. Ed. Paul Goring. London: Penguin.

Stone, Lawrence. 1977. The Family, Sex and Marriage in England, 1500-1800. New York: Harper \& Row.

Strick, Simon. 2014. American Dolorologies. Pain, Sentimentalism, Biopolitics. Albany: State University of New York Press.

Sussman, Charlotte. 2000. Consuming Anxieties. Consumer Protest, Gender, and British Slavery, 1713-1833. Stanford: Stanford University Press.

Swaminathan, Srividhya. 2009. Debating the Slave Trade. Rhetoric of British National Identity, 1759-1815. Farnham: Ashgate.

Tamarkin, Elisa. 2002. Black Anglophilia; or, The Sociability of Antislavery. American Literary History 14 (3): 444-478. 
Thackeray, William Makepeace. 2003 [1848]. Vanity Fair. A Novel Without a Hero. Ed. John Carey. London: Penguin.

Thomas, Helen. 2000. Romanticism and Slave Narratives. Transatlantic Testimonies. Cambridge: Cambridge University Press.

Todd, Janet. 1986. Sensibility. An Introduction. London: Methuen.

- 2000. Fatal Fluency: Behn's Fiction and the Restoration Letter. EighteenthCentury Fiction 12 (2-3): 417-434.

Tosh, John. 1999. A Man's Place. Masculinity and the Middle-Class Home in Victorian England. New Haven: Yale University Press.

- 2004. Manliness and Masculinities in Nineteenth-Century Britain. Essays on Gender, Family, and Empire. Harlow: Pearson Longman.

Walvin, James. 2007. Britain's Slave Empire. Stroud: Tempus.

Warner, William Beatty. 2000. Staging Readers Reading. Eighteenth-Century Fiction 12 (2-3): 391-416.

Watson, Tim. 2013. Postcolonial Studies and Atlantic Studies: Interdisciplinary Reflections on Slavery and Empire. In Postcolonial Studies across the Disciplines, ed. Jana Gohrisch and Ellen Grünkemeier, 3-21. Amsterdam: Rodopi.

Watt, Ian. 2000 [1957]. The Rise of the Novel. Studies in Defoe, Richardson and Fielding. London: Pimlico.

Weber, Florian. 2008. Von den klassischen Affektenlehren zur Neurowissenschaft und zurück. Wege der Emotionsforschung in den Geistes- und Sozialwissenschaften. Neue Politische Literatur 53: 21-42.

Wedderburn, Robert. 1991 [1824]. The Horrors of Slavery and Other Writings by Robert Wedderburn. Ed. Iain McCalman. Edinburgh University Press.

Werner, Michael, and Bénédicte Zimmermann. 2006. Beyond Comparison: Histoire Croisée and the Challenge of Reflexivity. History and Theory 45 (1): 30-50.

Williams, Raymond. 1985 [1977]. Marxism and Literature. Oxford: Oxford University Press.

Wollstonecraft, Mary. 1992 [1792]. A Vindication of the Rights of Woman. Ed. Miriam Brody. London: Penguin.

Wood, Marcus. 2002. Slavery, Empathy, and Pornography. Oxford: Oxford University Press.

Woodard, Helena. 1999. African-British Writings in the Eighteenth Century. The Politics of Race and Reason. Westport: Greenwood Press.

Wright, Michelle M. 2004. Becoming Black. Creating Identity in the African Diaspora. Durham: Duke University Press.

Young, Robert. 1995. Colonial Desire. Hybridity in Theory, Culture, and Race. London: Routledge. 
Open Access This chapter is licensed under the terms of the Creative Commons Attribution 4.0 International License (http://creativecommons.org/licenses/ by $/ 4.0 /$ ), which permits use, sharing, adaptation, distribution and reproduction in any medium or format, as long as you give appropriate credit to the original author(s) and the source, provide a link to the Creative Commons licence and indicate if changes were made.

The images or other third party material in this chapter are included in the chapter's Creative Commons licence, unless indicated otherwise in a credit line to the material. If material is not included in the chapter's Creative Commons licence and your intended use is not permitted by statutory regulation or exceeds the permitted use, you will need to obtain permission directly from the copyright holder. 